\title{
With All My Worldly Goods I Thee Endow, or Maybe Not: A Reevaluation of the Uniform Premarital Agreement Act After Three Decades
}

\author{
J. THOMAS OLDHAM*
}

\section{INTRODUCTION}

As Hogarth reminds us, in English society when children of the wealthy marry it has been common for centuries for the parties (or their parents) to negotiate an agreement before marriage regarding the couple's finances. ${ }^{1}$ In more recent times in the United States, couples marrying later in life after raising children with another partner frequently have signed premarital agreements clarifying their respective inheritance rights, and such agreements have generally been enforced. What is relatively new in Anglo-American law is the acceptance of the idea that prospective spouses via a premarital agreement can alter the parties' respective rights and obligations if they divorce.

This novel idea (for a non-civil law country) was first announced in the U.S. in an opinion written by the Florida Supreme Court in $1970 .^{2}$ In the early 1980s, the National Conference of Commissioners on Uniform State Laws authorized a group to attempt to draft a uniform law outlining the rules that should govern how to determine whether to enforce such an agreement. The result was the Uniform Premarital Agreement Act (the UPAA), which was promulgated in 1983. Since then, some states have adopted the UPAA. Many have not adopted it or have adopted it with some modifications.

During the past four decades, all U.S. states have accepted the general idea that spouses may make an enforceable agreement specifying the economic consequences of divorce. There is substantial disagreement, however, regarding whether the right to spousal support can be affected, as well as which rules ought to be applied to determine whether to enforce the agreement. States disagree both as to the mandated procedural requirements for entering into such agreements as well whether there should be some sort of review of the

* John Freeman Professor of Law, University of Houston Law Center. I would like to thank Professors Bill Atkin, Nick Bala, Nina Dethloff, and Patrick Parkinson for help with the comparative information set forth in this article. Barbara Atwood, Naomi Cahn, June Carbone and Judith Younger provided helpful comments to earlier drafts. I would also like to thank UHLC law student Lisa Baiocchi-Mooney for her research assistance, Dan Baker for obtaining numerous books, periodicals, and cases from the library, and Amanda Parker for her speedy and careful administrative help.

1. See Hogarth'S MARRIAge À-LA-Mode (Judy Egerton, ed. 1997); Lloyd Bonfield, Property Settlements on Marriage in England from the Anglo-Saxons to the Mid-Eighteenth Century, in MARRIAGE, PROPERTY, AND SUCCESSION 287, 292-93 (Lloyd Bonfield ed., 1992); LAWRENCE STONE, THE FAMILY, SEX AND MARRIAGE IN ENGLAND 1500-1800, at 30-31, 87 (1977). For a French perspective, see generally HONORÉ DE BALZAC, THE MARRIAGE CONTRACT (1835).

2. Posner v. Posner, 233 So. 2d 381 (Fla. 1970). 
substantive fairness of the agreement either at the time of signing or at divorce. The UPAA reflects a policy judgment that there should not be substantial procedural requirements for entering into such agreements and that no review of the fairness of the agreement at divorce is appropriate. In this regard, the policy judgments reflected in the UPAA differ from those adopted in a number of other states and other countries during the three decades since promulgation of the UPAA.

In 2010, the National Conference of Commissioners on Uniform State Laws appointed a committee to draft a new uniform act to set forth, among other things, standards for determining the enforceability of premarital agreements. The committee presumably will review the UPAA and consider whether any modification of the UPAA would now be appropriate. ${ }^{3}$ This article will compare the provisions of the UPAA to the rules now applied in states that have not adopted the UPAA and in other countries to determine when to enforce a premarital agreement that contemplates divorce. I will argue that the UPAA is not consistent with the consensus evolving in other states and countries regarding what needs to be established before a premarital agreement should be enforced. I will suggest various possible amendments to the UPAA so the UPAA could be made more consistent with rules in other states and international trends.

\section{StATES THAT HAVE AdOPTED THE UPAA}

\section{A. Those States That Adopted the UPAA in Its Entirety}

Thirteen states have adopted the UPAA with no significant changes. ${ }^{4}$ The uniform act authorizes both the restriction or elimination of divisible property upon divorce ${ }^{5}$ and the restriction or elimination of spousal support. ${ }^{6}$ A waiver of spousal support is effective unless the lack of support would cause a party to become a public charge; if this would occur, the court is authorized to award support in an amount sufficient to avoid such a result. ${ }^{7}$ An agreement is presumptively valid, and the person challenging the agreement has the burden to show it is not enforceable. To overturn an agreement, the challenging party must show either that the agreement was: (i) not signed "voluntarily" (not

3. To view the Committee list and links to related documents, see Premarital and Marital Agreements, UNIF. LAW COMM'N, http:/ / www.uniformlaws.org/committee.aspx?title=Premarital\%20 and\%20marital\%20Agreements (last visited Jan. 10, 2012). The committee expects to present a draft for final approval in July 2012. Id.

4. See ARIZ. Rev. STAT. ANN. § 25-201 et seq. (2011); ARK. CODE ANN. § 9-11-401 et seq. (2009); Del. Code ANN. Tit. 13, § 321 et seq. (2009); HAW, REV. STAT. § 572D-1 et seq. (2010); IDAHO CODE ANN. § 32-921 et seq. (2006); 750 ILl. COMP. STAT. ANN., 40/2601 et seq. (West 2011); KAN. STAT. ANN. § 23801 et seq. (2007); MONT. CODE ANN. § 40-2-601 et seq. (2011); NEB. REV. STAT. § 42.1001 et seq. (2011); N.C. Gen. StAT. ANN. § 52B-1 et seq. (West 2010); OR. ReV. STAT. § 108.700 et seq. (2009); TeX. FAM. CODE ANN. § 4.001 et seq. (Vernon 2011); VA. CODE ANN. § 20-147 et seq. (2011); D.C. CODE § $46-501$ et seq. (2005).

5. UNIF. PREMARITAL AGREEMENT ACt, §3(3), 9C U.L.A. 43 (2001).

6. See id. $\S 3(4)$.

7. See id. $\S 6(\mathrm{~b})$. 
defined) 8 or (ii) "unconscionable" (not defined) when signed, and that the person challenging the agreement did not receive adequate disclosure of financial information regarding the other party, did not waive the right to such information, and did not otherwise have access to such information. ${ }^{9}$ In other words, an agreement that is unconscionable when signed is still enforceable if there was adequate disclosure of financial information, a waiver of the right to disclosure, or the party otherwise had access to such information. Any change in the circumstances of the parties after the wedding is not relevant to the issue of enforcement. The receipt of advice from independent counsel might be relevant to the issue of voluntary execution but is not required. ${ }^{10}$

\section{B. Those Adopting States That Made Changes to the UPAA}

\section{i. Voluntary Execution}

In contrast to the thirteen states that adopted the UPAA without substantial revision, a significant number of other states chose to adopt the UPAA, but only after some revisions. For example, the California version of the UPAA contains significant changes. ${ }^{11}$ The UPAA specifies that an agreement should not be enforced if it is not signed voluntarily; 12 no definition of voluntariness is given, nor are any factors listed that should be taken into consideration when making this determination. In contrast, the California statute attempts to clarify the standard for voluntary execution. The statute specifies that an agreement should be found to be voluntarily signed only if: (i) the party against whom enforcement is sought either had independent counsel or waived that right in writing; (ii) the party against whom enforcement is sought was given at least seven days to consider whether to sign the agreement; and (iii) the party against whom enforcement is sought, if unrepresented by counsel, was fully informed in writing of the terms and basic effect of the agreement as well as the rights and obligations he or she was giving up by signing the agreement. ${ }^{13}$

Other state versions of the UPAA have modified the provision pertaining to voluntary execution. The Florida statute lets a party challenge an agreement either on the ground of "involuntariness" or by showing that the agreement was procured by "fraud, duress, coercion or overreaching." 14 In Rhode Island, an agreement may be challenged only if it is shown that the agreement was not voluntarily signed, the agreement was unconscionable when signed, and the challenging party did not receive adequate financial information. ${ }^{15}$

8. See id. $\S 6(a)(1)$.

9. See id. $\S 6(\mathrm{a})(2)$.

10. See generally id. \$6.

11. See CAL. FAM. CODE $§ 1615$ (c) (West 2004).

12. See Unif. PREMARItAl AgreEMENT ACt § 6(a)(1).

13. See CAL. FAM. CODE $§ 1615$ (c).

14. See Fla. StAT. ANN. $\$ 61.079$ (7) (West 2011).

15. See R. I. GEN. LAWS $§ 15-17-6$ (2003). 


\section{ii. Unconscionability}

Likewise, many states that have adopted the UPAA changed the rules applicable to challenging the agreement based on unconscionability. To challenge an agreement under the UPAA on the ground of unconscionability, the uniform act requires a substantial showing. ${ }^{16}$ First, the agreement must be found to be unconscionable at the time of signing (not at the time of divorce). ${ }^{17}$ If this is established, the challenging party must also show that the financial disclosure to that party was inadequate, that the objecting party did not waive the right to such disclosure, and that the objecting party did not otherwise know that information. ${ }^{18}$

A number of states have modified this provision in some manner. For example, under the Connecticut provision, the agreement is not to be enforced if it is unconscionable either at the time of signing or when it is to be enforced. ${ }^{19}$ An agreement can be successfully challenged in Indiana or Nevada by establishing that the agreement was unconscionable at the time of signing, regardless of whether there was adequate disclosure of financial information. ${ }^{20}$ In New Jersey, an agreement can be successfully challenged if unconscionable when enforcement is sought. ${ }^{21}$ In North Dakota, if enforcement of the agreement would be unconscionable, the court may: (i) refuse to enforce it in its entirety, (ii) enforce a severable portion of the agreement without the unconscionable provisions, or (iii) limit the application of the unconscionable provisions to avoid an unconscionable result. ${ }^{22}$

The UPAA does not define "unconscionable."23 One state has attempted to clarify the meaning of this term. In New Jersey, an agreement is unconscionable if it leaves a party without a means of reasonable support or would provide a standard of living for a party far below what the party enjoyed before the marriage. ${ }^{24}$

\section{iii. Limiting Spousal Support}

The UPAA authorizes the elimination of spousal support and does not permit a review of the fairness of such a provision at divorce unless the waiving party would become a public charge. Some states have made it easier to challenge an alimony waiver. For example, in Indiana an alimony waiver is not fully enforceable if the waiver would cause extreme hardship under circumstances not reasonably foreseeable at the time of signing. ${ }^{25}$ If this occurs,

16. See Unif. Premarital AgreEMENT ACt § (6)(a)(2).

17. See id.

18. See id.

19. See CONN. Gen. STAT. ANN. § 46b-36g(a)(2) (West 2009).

20. See Ind. CODE ANN. § 31-11-3-8 (West 2001); NEV. ReV. STAT. § 123A.080 (2010).

21. See N.J. STAT. ANN. § 37:2-37 (West 2002).

22. See N.D. CENT. CODE § 14-03.1-07 (2009).

23. See UnIf. PREMARITAL AgreEMENT ACt $\S 1$.

24. See N.J. STAT. ANN. § 37:2-32 (West 2011).

25. See IND. CODE ANN. § 31-11-3-8. 
the court may award support to the extent necessary to avoid that hardship. ${ }^{26}$ In Iowa, South Dakota, and New Mexico, an agreement cannot impact the right to spousal support. ${ }^{27}$ Additionally, a waiver of spousal support could be challenged as unconscionable at the time of divorce in Connecticut, New Jersey, or North Dakota, as discussed in the preceding section. ${ }^{28}$

California sets forth more detailed rules regarding agreements limiting spousal support. A provision restricting the right to spousal support is not enforceable if: (i) the party against whom enforcement is sought was not represented by independent counsel in connection with signing the agreement, or (ii) the provision is unconscionable at the time of enforcement. ${ }^{29}$

iv. Inadequate Disclosure

In some "adopting" states, an agreement is not enforceable if the challenging party was not given fair and reasonable financial information, did not waive the right to such information, and did not already know the information, regardless of whether the agreement was also unconscionable when signed. ${ }^{30}$ The Connecticut statute seems to compel financial disclosure; there is no mention of satisfying this requirement via a waiver or some other way of informally acquiring this information. ${ }^{31}$ In Arkansas, a waiver of the right to receive disclosure of financial information is valid only if the party was represented by counsel. ${ }^{32}$

Under the UPAA the challenging party must show that he or she did not receive "fair and reasonable" disclosure. ${ }^{33}$ The California statute demands proof of "fair, reasonable and full" disclosure. ${ }^{34}$

\section{v. Other Provisions}

Some states that adopted the UPAA have added additional rules. For example, in Maine an agreement is void eighteen months after the parties become biological or adoptive parents unless the parties reaffirm the agreement during that period. ${ }^{35}$

26. Id.

27. See IowA Code ANN. § 596.5 (West 2001); N. M. STAt. ANN. § 40-3A-4 (2011); Sanford v. Sanford, 694 N.W.2d 283, 289 (S.D. 2005).

28. See Conn. Gen. Stat. AnN. § 46b-36g(a)(2) (West 2009); N.J. Stat. AnN. § 37:2-37; N.D. CENT. CODE $§ 14-03.1-07$ (2009).

29. CAL. FAM. CODE $§ 1612$ (West 2004).

30. See IowA Code ANN. § 596.8(3); NeV. ReV. StAT. ANN. § 123A.080 (LexisNexis 2010); N.J. STAT. ANN. § 37.2-38(c).

31. See CONN. GEN. STAT. Ann. § 46b-36g (West 2009).

32. ARK. CODE ANN. §9-11-406(a)(2)(ii) (2009).

33. See UNIF. PREMARITAL AGREEMENT ACt § 6(a)(2), 9C U.L.A. 49 (2001).

34. See CAL. FAM. CODE § 1615(a)(2)(A).

35. See ME. REV. STAT. ANN. tit. 19-A § 606 (1998). This provision does not apply to agreements signed after October 1, 1993. Id. For a general survey of the manner in which some adopting states modified the UPAA, see generally Amberlynn Curry, The Uniform Premarital Agreement Act and Its Variations Throughout the States, 23 J. AM. ACAD. MATRIM. LAW. 355 (2010). 


\section{Summary}

About half of all states have adopted the UPAA in some form. However, before enactment many adopting states altered the uniform law in one or more material ways that make it easier to challenge a premarital agreement. For example, in some states the unconscionability of the agreement is to be determined at divorce, not the time of signing, and in a number of states a finding of unconscionability alone is grounds for a successful challenge. Others do not permit a limitation on the right to spousal support or require independent counsel as a condition of such a provision. California has endeavored to clarify how to determine whether an agreement was signed "voluntarily," while New Jersey has attempted to define what an "unconscionable" agreement is. If the parties have a biologic or adoptive child during marriage, to maintain the effectiveness of the agreement for agreements signed before 1993, Maine required parties to reaffirm the agreement soon after the arrival of a biological or adoptive child. So, a significant number of "adopting" states disagree with one or more basic policy judgments reflected in the UPAA.

\section{PROCEDURAL SAFEGUARDS}

About half of all states have not adopted the UPAA, and many apply standards significantly different from the UPAA to determine whether to enforce such agreements. The discussion below compares the policy judgments incorporated into the UPAA to the rules now applied in states that have not adopted the UPAA to determine whether to enforce a premarital agreement.

\section{A. Voluntary Execution}

Almost all states theoretically require premarital agreements to be signed voluntarily or without duress. States have tended to construe both terms similarly.

\section{i. Involuntariness}

While the UPAA requires voluntary execution, it provides no additional guidance about how to determine whether execution is voluntary or involuntary. The California Supreme Court discussed the factors it felt should be relevant to a determination of voluntary execution in In re Marriage of Bonds. ${ }^{36}$ The court concluded that these factors should focus on: the relative bargaining power of the parties; whether there was coercion; whether the agreement was signed shortly before the wedding; the presence of independent counsel for the waiving party; and whether the waiving party understood the terms, purpose, and effect of the agreement. ${ }^{37}$ Since the Bonds case, some other courts have generally approved of this analysis. ${ }^{38}$

36. In re Marriage of Bonds, 5 P.3d 815, 824-26 (Cal. 2000).

37. Id. at 824-26.

38. See In re Estate of Smid, 756 N.W.2d 1, 16 (S.D. 2008); In re Marriage of Rudder, 217 P.3d 183, 189-91 (Or. Ct. App. 2009). 
The Connecticut Supreme Court has stated that "the timing of the agreement is of paramount importance in assessing whether [an agreement was voluntarily signed]." 39 Another approach is to look to Black's Law Dictionary, which defines "voluntary" as "intentionally; without coercion." 40 Some courts equate a voluntarily executed premarital agreement with one free from duress or undue influence. ${ }^{41}$ Duress requires a wrongful or unlawful threat which gives the other party no reasonable alternative. ${ }^{42}$ Undue influence is influence that deprives a person of his or her freedom of choice. ${ }^{43}$

Regardless of whether UPAA courts apply the Bonds factors to determine voluntary execution or consider whether there was duress or undue influence, what is remarkable is that many courts have upheld the agreement despite unfair bargaining tactics. Although in rare instances a premarital agreement provides additional rights to the spouse with fewer assets, ${ }^{44}$ the "stereotypic" voluntary execution case involves this scenario: the wealthier party decides he or she wants a premarital agreement to limit the other party's financial claims if the parties divorce. ${ }^{45}$ The wealthier party instructs his or her lawyer to draft an agreement

39. Friezo v. Friezo, 914 A.2d 533, 551 (Conn. 2007) (quoting 41 Am. Jur. 2d Husband and Wife § 101).

40. BLACK'S LAW DICTIONARY 1605 (8th ed. 2004). For cases that have considered this definition, see In re Rudder, 217 P.3d at 190; In re Marriage of Shanks, 758 N.W.2d 506, 512 (Iowa 2008).

41. See In re Shanks, 758 N.W.2d at 512.

42. Id. at 513 .

43. Id.

44. See Marsh v. Marsh, 949 S.W.2d 734, 737-38 (Tex. App. 1997); Weber v. Weber, 589 N.W.2d 358, 359 (N.D. 1999); Carnell v. Carnell, 398 So.2d 503 (Fla. App. 1981).

45. See In re Estate of Hollett, 834 A.2d 348 (N.H. 2003) (involving a party desiring an agreement who had a net worth of $\$ 6,000,000$ while the other party's assets were worth $\$ 5,000)$; Mallen v. Mallen, 622 S.E.2d 812 (Ga. 2005) (involving proponent with net worth of $\$ 8,500,000$ while the other party's assets were worth \$10,000); Hoag v. Dick, 799 A.2d 391 (Me. 2002) (involving proponent of agreement who owned assets worth more than $\$ 1,000,000$ while the other owned assets of "negligible value"); Bakos v. Bakos, 950 So.2d 1257 (Fla. Dist. Ct. App. 2007) (involving proponent's assets worth $\$ 800,000$ with the other's worth \$12,000); Potts v. Potts, 303 S.W.3d 177 (Mo. Ct. App. 2010) (involving proponent who had assets of $\$ 627,000$ while the other party's assets were worth $\$ 5,000$ ); Hiemstra v. Hiemstra, 2010 WL 1433880 (N.J. Super. Ct. App. Div. 2010) (involving proponent who had a net worth of about $\$ 6$ million while the other party's net worth was less than $\$ 200,000)$; Austin v. Austin, 839 N.E.2d 837 (Mass. 2005) (involving proponent's net worth of $\$ 1,000,000$ where the waiving party's assets were worth \$35,000); Wiethe v. Beaty, 1999 WL 74595 (Ohio Ct. App. 1999) (involving proponent who owned $\$ 2,000,000$ in assets while the other party owned assets worth $\$ 441,000)$; McKee-Johnson v. Johnson, 444 N.W.2d 259 (Minn. 1989) (involving proponent with net worth of $\$ 1,400,000$ while the other party's assets were worth $\$ 100,000)$; In re Marriage of Bonds, 5 P.3d 815 (Cal. 2000) (involving proponent whose annual income at the time of signing was $\$ 106,000$ in the late 1980s and likely to increase while the waiving party "had worked as a waitress and a bartender"); Edwards v. Edwards, 744 N.W.2d 243 (Neb. Ct. App. 2008) (involving proponent's assets which exceeded $\$ 1,700,000$ while the waiving party's assets were worth $\$ 28,000$ ); In re Marriage of Barnes, 755 N.E.2d 522 (Ill. App. Ct. 2001) (involving proponent's annual salary which was "in excess of" $\$ 250,000$ (plus "various perks") at the time of execution while the waiving party's annual salary was $\$ 19,000$ ); Margulies v. Margulies, 491 So.2d 581 (Fla. Dist. Ct. App. 1986) (involving proponent who had a net worth of at least $\$ 50$ million while the other party was a flight attendant); Sogg v. Nev. State Bank, 832 P.2d 781 (Nev. 1992) (involving proponent's net worth of $\$ 20$ million where the other party did not have "substantial financial resources"); Warren v. Warren, 523 N.E.2d 680 (Ill. App. Ct. 1988) (involving proponent who was a multimillionaire while the other party was a secretary); DeMatteo v. 
that protects that party and limits the claims of the other party (or perhaps even eliminates such claims) if the parties divorce. The wealthier party then presents the agreement to the other party shortly before the planned wedding, frequently a day or two before, and states that he or she is willing to marry only if the agreement is signed. ${ }^{46}$ This leaves the less wealthy party belatedly learning of the agreement in a very difficult situation. That party has to decide whether to try to get legal advice and, if legal advice is desired, to determine how to obtain competent advice within twenty-four or forty-eight hours, and perhaps on a weekend day when most lawyers are not in their offices. Then the party must attempt to negotiate the agreement at the last minute and decide whether to sign the agreement or postpone or cancel the wedding after guests from out of town have begun to arrive.

In many cases, the wealthy party presents the agreement and states that he or she will not marry unless it is signed. This is generally not perceived by courts to be unfair bargaining. Each party is thought to be under no obligation to marry and can set forth certain prerequisites and conditions that must be satisfied before he or she will marry.47 As a general principle, it is not unfair bargaining for a person to specify to his partner the terms based upon which the party would be willing to marry. Whether it is unfair bargaining to present an agreement at the last minute and then tell your partner that the marriage will occur only if the partner signs it is another matter.

DeMatteo, 762 N.E.2d 797 (Mass. 2002) (involving proponent who owned assets valued in excess of $\$ 83$ million while the other party had a net worth of less than \$5,000); Friezo v. Friezo, 914 A.2d 533 (Conn. 2007) (involving proponent with net worth of $\$ 6.5$ million, while the other party owned assets amounting to \$22,000); Gardner v. Gardner, 527 N.W.2d 701 (Wis. Ct. App. 1994) (involving proponent whose assets amounted to more than $\$ 3$ million while the assets of the other party amounted to \$22,000); Adams v. Adams, 603 S.E.2d 273 (Ga. 2004) (involving proponent whose assets were valued at $\$ 4,526,708$ while the other party's were worth $\$ 30,000$ ); In re Marriage of Berger, 829 N.E.2d 876 (Ill. App. Ct. 2005) (involving proponent who owned assets worth $\$ 10$ million while the other party's net worth was \$149,000); Millstein v. Millstein, 2002 WL 31031676 (Ohio Ct. App. 2002) (involving proponent whose net worth was \$28 million while the other party's assets were worth $\$ 10,000)$. This certainly is the normal assumption lawyers make about the purpose of a premarital agreement. See, e.g., Premarital Agreement Basic Form: Anticipating the Needs of the Monied Spouse, 18 FAM. ADVOC., Summer 1995, at 8-9. Professor Atwood notes that the party being asked to waive rights frequently is the woman. See Barbara Ann Atwood, Ten Years Later: Lingering Concerns About the Uniform Premarital Agreement Act, 19 J. Legis. 127, 133 n.29 (1993). Of course, women do sometimes propose a premarital agreement to protect their wealth. For example, the recent highly publicized case of Radmacher v. Granatino decided by the English Supreme Court involved an agreement intended to protect Ms. Radmacher's wealth. See Ian Cowie, Hedging Your Romantic Bets, Daily Telegraph, Oct. 23, 2010, at 11. Britney Spears signed a premarital agreement with Kevin Federline that eventually limited his financial claims in their divorce. See Jamie Doward, Prenuptial Agreements on Rise Amongst Younger Men, Observer, July 17, 2010, http://www.guardian.co.uk/lifeandstyle/2010/jul/18/prenuptial-agreements-rise-males. John Kerry signed a premarital agreement before he married Teresa Heinz. Id.

46. For example, the Supreme Court of Ohio has stated: "Our research has disclosed that it is a common practice to present antenuptial agreements at the eleventh hour before the wedding ceremony." See Fletcher v. Fletcher, 628 N.E.2d 1343, 1348 (Ohio 1994).

47. See, e.g., Mallen v. Mallen, 622 S.E.2d 812, 815 (Ga. 2005); Osorno v. Osorno, 76 S.W.3d 509, 511 (Tex. App. 2002); Francavilla v. Francavilla, 969 So.2d. 522, 525 (Fla. Dist. Ct. App. 2007); Liebelt v. Liebelt, 801 P.2d. 52 (Idaho. App. 1990). See generally J.T. OLDHAM, DivORCE, SEPARATION AND THE DISTRIBUTION OF PROPERTY (2010) § 4.03[4] nn.72 \& 73.. 
In some cases of this nature, courts have concluded the agreement was involuntarily signed. ${ }^{48}$ For example, in Marriage of Rudder, ${ }^{49}$ the parties planned to meet at the office of the husband's lawyer the day before they were to leave town to marry.50 The wife asked her prospective husband and his lawyer to be sure that her long-time lawyer would also be present to give her advice. ${ }^{51}$ When she arrived at the meeting, her lawyer was not there, apparently because neither her husband nor his lawyer notified her lawyer of the meeting. ${ }^{52}$ The husband gave the wife a draft of the agreement, which waived all marital rights and the right to claim spousal support. ${ }^{53}$ The husband's financial disclosure was general and did not attempt to place a value on any of his assets. ${ }^{54}$ The husband encouraged the wife to sign the agreement even though her lawyer had not reviewed it or discussed it with her. ${ }^{55}$ She signed the agreement. ${ }^{56}$ The trial court found the wife was relatively unsophisticated in financial matters. ${ }^{57}$ The appellate court affirmed the trial court's ruling that the agreement was involuntarily signed. ${ }^{5}$

In another case, 59 the prospective bride quit her job, lost her housing, and traveled from Russia to Montana intending to marry her fiancé. ${ }^{60}$ If she did not marry him, she could not remain in the U.S. ${ }^{61}$ Shortly before the wedding, after she had come to the U.S., the husband presented her with a premarital agreement drafted by his lawyer. ${ }^{62}$ The husband hired a lawyer to talk to his prospective wife, who did not understand much English, and the lawyer selected did not speak Russian. ${ }^{63}$ The wife signed the agreement. ${ }^{64}$ The trial court found that the prospective wife had quit her previous job and come to Montana (bringing with her a child from a prior relationship) with "extremely limited assets." 65 Her prospective husband stated he would not marry without a signed premarital agreement. ${ }^{66}$ If she didn't marry him, she would need to somehow find the resources to return to Russia with her child and find a job and a place to

48. See generally OLDHAM, DIVORCE, SEPARATION, supra note 47 at § 4.03[4] n.58.

49. 217 P.3d 183 (Or. Ct. App. 2009).

50. Id. at 188 .

51. Id.

52. Id.

53. Id.

54. Id.

55. Id.

56. Id.

57. Id. at 195 .

58. Id. at 194.

59. In re Marriage of Shirilla, 89 P.3d 1 (Mont. 2004).

60. Id. at 2 .

61. She had come to the U.S. on a "fiancée visa." Id.

62. Id.

63. Id. at 3 .

64. Id.

65. Id. at 4 .

66. Id. 
live. ${ }^{67}$ The Montana Supreme Court found the negotiations coercive and upheld a finding of involuntariness. ${ }^{68}$

In Kornegary v. Robinson, 69 the parties became engaged in "early October" 1990 and decided to marry October $12 .{ }^{70}$ On October 11, the man told the woman he wanted a premarital agreement. ${ }^{71}$ The day of the wedding, the parties went to the office of the husband's lawyer to review the agreement that had been drafted. ${ }^{72}$ The woman was generally told that it limited her rights on divorce. ${ }^{73}$ She signed it without reading it or consulting a lawyer. ${ }^{74}$ The marriage ended when the husband died. ${ }^{75}$ Contrary to what the wife was told, the agreement limited her rights regardless of whether the marriage ended by death or divorce. ${ }^{76}$ The trial court granted summary judgment on behalf of the husband's estate that the agreement was voluntarily signed and enforceable. ${ }^{77}$ The court of appeals, however, noted that the wife had only a high school education and was unsophisticated. ${ }^{78}$ In addition, the agreement was presented at the last minute, the husband's financial disclosure was incomplete, and the wife did not consult with counsel. ${ }^{79}$ The court of appeals concluded that material issues of fact existed regarding whether the agreement was voluntarily signed, so the summary judgment motion ruling was reversed. ${ }^{80}$

A few other somewhat recent cases have declined to enforce an agreement presented at the last minute. In one case, the agreement was presented on the wedding day and the parties signed it in the church parking lot immediately before the wedding. ${ }^{81}$ In another case, an agreement signed the day before the wedding was not enforced. ${ }^{82}$ A third court held that an agreement was involuntarily signed when it was presented and signed two days before the wedding; the court emphasized the disparity in the parties' respective ages,

67. Id.

68. Id. See also Azarova v. Schmitt, No. C-060090, 2007 WL 490908 (Ohio Ct. App. 2007); A.E.S. v. S.N.S., No. CN01-07370, 2006 WL 2389314 (Del. Fam. Ct. 2006); Chaplain v. Chaplain, 682 S.E.2d 108 (Va. Ct. App. 2009); Holler v. Holler, 612 S.E.2d 469 (S.C. Ct. App. 2005).

69. 625 S.E.2d 805 (N.C. App. Ct. 2006), rev'd, 637 S.E.2d 516 (N.C. 2006).

70. Kornegary, 625 S.E.2d at 806.

71. Id.

72. Id.

73. Id.

74. Id.

75. Id.

76. Id.

77. Id. at 807 .

78. Id. at 808-09.

79. Id. at 809 .

80. Id. at 810

81. See Hoag v. Dick, 799 A.2d 391 (Me. 2002) (applying pre-UPAA case law to determine the agreement was unenforceable). In Pember v. Shapiro, 794 N.W.2d 435 (N.D. 2011), the North Dakota Supreme Court affirmed a finding of involuntary execution when the agreement was drafted and signed hours before the wedding.

82. See Bakos v. Bakos, 950 So.2d 1257, 1259 (Fla. Dist. Ct. App. 2007) (affirming a finding of undue influence). See also In re Marriage of Tamraz, 2005 WL 1524199 at *5-6 (Cal. Ct. App. 2005). 
sophistication, and bargaining power. ${ }^{83}$

Washington has applied a more robust procedural standard for enforceable premarital agreements. In re Marriage of Bernard ${ }^{84}$ involved a prenuptial agreement signed by a very rich man and a poor prospective bride. 85 The man gave the woman the first draft of the agreement about two weeks before the wedding date. ${ }^{86}$ The woman met with a lawyer three days before the wedding, apparently to go over the draft she had been given. ${ }^{87}$ That evening, her lawyer received a substantially revised draft. 88 The groom said he would call off the wedding if she did not sign. ${ }^{89}$ The woman's lawyer said it was very difficult to contact his client in light of the many wedding details and guests she was dealing with..$^{90}$ She signed the agreement the day before the wedding. ${ }^{91}$ The Washington Supreme Court affirmed the trial court's ruling that the woman did not sign the agreement "voluntarily or intelligently." 92

However, the above cases invalidating the premarital agreements seem to be exceptions; in many instances, such agreements presented at the last minute are found to be voluntarily signed. ${ }^{93}$ This result largely flows from how the issue is framed-the agreement is perceived to be voluntarily signed unless the proponent made an unlawful threat or the objecting party was forced to sign it. This is a difficult standard to satisfy. For example, in Texas the UPAA has been in effect for more than two decades, and in no appellate case so far has a premarital agreement been considered involuntarily signed.

One recent example of this approach is In re Estate of Smid. ${ }^{94}$ In that case, the husband was dying of cancer.95 During the week he eventually died, his son from a prior marriage became concerned about his father's lack of estate planning, and he asked a lawyer to meet with his father. ${ }^{96}$ The lawyer met with the husband and his wife and discussed his recommendation. ${ }^{97}$ The lawyer prepared documents to transfer ownership of the husband's property to a trust; included was a waiver by the wife of her statutory rights as a surviving spouse. ${ }^{98}$ The lawyer delivered the documents to the parties' home on January 29, 2003; he did not explain the documents to the wife, apparently due to the understanding

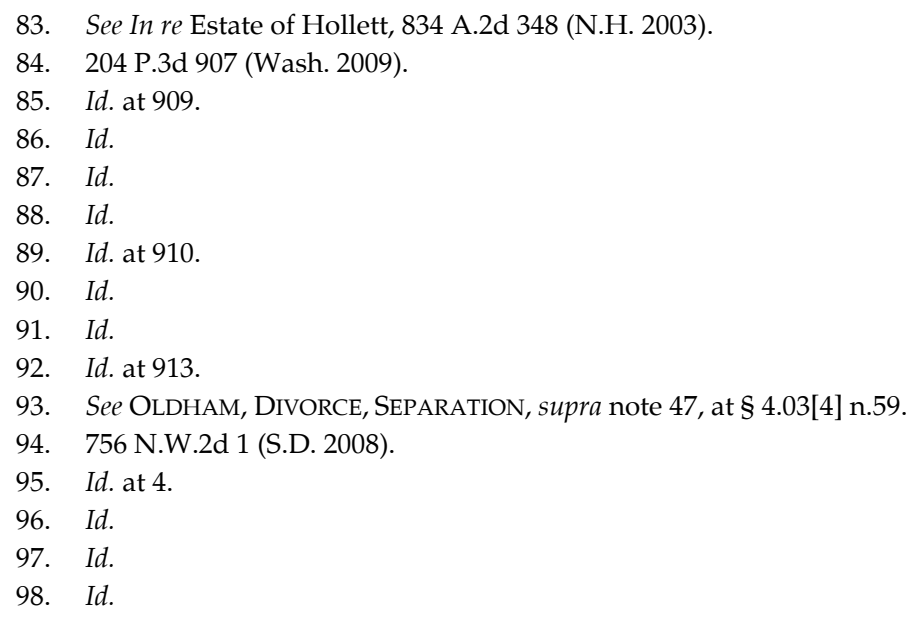


he was representing the husband. ${ }^{99}$ The wife did not obtain legal advice before she signed the documents that day. ${ }^{100}$ Later that evening, her husband died. ${ }^{101}$ Under South Dakota law, her waiver was not enforceable if involuntarily signed.102 The wife admitted she was not "physically forced" to sign. 103 Because of this, and because the trial court found that her husband's impending death did not interfere with her ability to understand and comprehend events, the court affirmed the finding of voluntary execution. ${ }^{104}$

Likewise, in Brown $v$. Brown, 105 the wealthy party gave the other a draft of the agreement a day before the wedding. ${ }^{106}$ That party tried to contact her lawyer a few times that day but could not reach the lawyer. ${ }^{107}$ She then signed the agreement.108 The court rejected the woman's later claim that the presentation of the agreement the day before the wedding, when preparations for the wedding had already been made and out-of-town guests had already arrived, at a time when obtaining legal advice was hampered by time constraints, created a coercive atmosphere. ${ }^{109}$

Similarly, in the case In re Estate of Ingmand, ${ }^{110}$ the groom asked his lawyer to prepare an agreement and, three days before the wedding, while telling his prospective bride they were going to get a marriage license, the man drove her to his lawyer's office to review and sign the premarital agreement. ${ }^{111}$ The appellate court affirmed the determination by the trial court that the agreement was valid, noting that:

For [the male] to somehow trick [the female] into going to [the lawyer's] office just days before their marriage, and then condition the marriage on her signature, was certainly not laudatory. However, while these actions may be fairly characterized as surprise pressure tactics, they do not negate the knowing and voluntary nature of the execution. ${ }^{112}$

Even if both parties have a lawyer, if a contract is presented at the last minute the negotiations can be quite confusing and frantically conducted due to the time pressure. For example, in the case In re Marriage of Murphy, ${ }^{113}$ the first

\footnotetext{
99. He apparently did discuss his general recommendations in the initial meeting. Id.

100. Id. at 5 .

101. Id.

102. Id.

103. Id. at 7.

104. Id. at 14 .

105. 26 So.3d 1210 (Ala. Ct. Civ. App. 2007).

106. Id. at 1212 .

107. On appeal, the Alabama Supreme Court noted that the agreement contained a recital that she had consulted with independent counsel before signing, so the trial court could reasonably disbelieve the woman's contention that she was not able to get legal advice. See 26 So.2d 1222 (Ala.

108. Brown, 26 So.3d at 1212.

109. Id. at 1215 .

110. No. 08-1281, 2001 WL 855406 (Iowa App. Ct. July 31, 2001).

111. Id. at *1.

112. Id. at *3.

113. 834 N.E.2d 56 (Ill. App. Ct. 2005).
} 2009). 
draft (written by the groom's lawyer) was exchanged two days before the wedding. ${ }^{114}$ The woman then contacted her lawyer and asked him to draft an alternate agreement. ${ }^{115}$ Her lawyer advised her not to sign the initial draft prepared by the man's lawyer.116 On the day of the wedding, the man and woman (but not her lawyer) went to the office of the man's lawyer to discuss changes to the draft his lawyer had prepared.117 After discussing some revisions, the man gave her a copy of a revised agreement three hours before the wedding was to begin. ${ }^{118}$ Without having her lawyer review the revised agreement, she signed it. ${ }^{119}$ The appellate court affirmed the finding of the trial court that, while the circumstances surrounding execution were certainly stressful, it was unlikely a product of coercion or duress. ${ }^{120}$

In another case, weeks before the planned wedding, the groom said he wanted the parties to sign a premarital agreement, and the woman said she would consider one.121 The evening before the parties were to go to Las Vegas to be married on New Year's Eve, the man gave the woman a draft of a premarital agreement and stated he would marry only if she signed. ${ }^{122}$ The trial court found that the woman had no time to discuss the agreement with a lawyer or anyone else due to the time the draft was first presented, so the trial court invalidated the agreement based on undue influence and duress. ${ }^{123}$ Although the court of appeals acknowledged the confidential relationship of people who are about to marry, it held that " $t \mathrm{t}]$ he mere shortness of the time ... between the presentation of the premarital agreement and the date of the wedding is insufficient alone to permit a finding of duress or undue influence;" further, "the shortness of the time interval when combined with a threat to call off the marriage if the agreement is not executed is likewise insufficient... to invalidate the agreement."124 Although the wife received the first draft of the agreement at 8:00 PM on December 30, with a planned wedding the next evening a substantial distance away, the appellate court concluded that, "we cannot presume ... that the wife had insufficient time to ... [consult] an attorney." 125

In DeLorean v. DeLorean, 126 the court considered whether to enforce an agreement presented by the husband "a few hours" before the wedding where he stated that he would cancel the wedding if the prospective bride did not sign. ${ }^{127}$ The agreement provided that all income and earnings of the parties

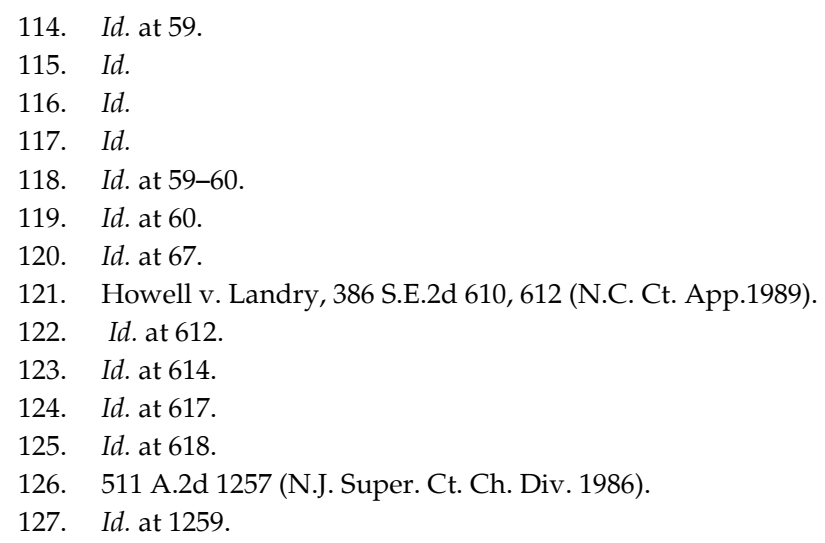


acquired before or during marriage would be exempt from equitable distribution if the parties divorced. ${ }^{128}$ The woman did consult with a lawyer who had been selected by the prospective husband to counsel her; the lawyer advised her not to sign. ${ }^{129}$ After some period of indecision, the wife did sign the agreement before the wedding. ${ }^{130}$ The court held that the agreement was voluntarily signed, noting that the wife "had sufficient time to consider the consequences of signing the agreement." 131

In another case, the party being asked to waive rights was given the agreement two days before it was to be signed.132 She argued that was overreaching. ${ }^{133}$ The appellate court stated that "two days... provided her ample opportunity to seek the advice of counsel before signing," and it affirmed the ruling that the agreement should be enforced. ${ }^{134}$

Pajak v. Pajak ${ }^{135}$ also involved an agreement presented by a sophisticated party to an unsophisticated party a day before the wedding. ${ }^{136}$ The court upheld the agreement. ${ }^{137}$

Other courts have concluded that, despite the agreement being presented at the last minute, the other party was not coerced into signing, so the agreement was voluntarily signed. ${ }^{138}$ Some courts have sensibly considered whether, despite the agreement being signed shortly before the wedding, the parties had agreed to the material terms substantially earlier. ${ }^{139}$ However, if the parties have only vaguely agreed to sign a premarital agreement without much clarity regarding the precise terms of the agreement, it seems unfair to treat such an agreement differently from any other agreement presented and negotiated shortly before the wedding. ${ }^{140}$

\section{ii. Duress}

Many non-UPAA states will not enforce an agreement if "duress" is found in connection with the negotiation and execution of the agreement. Duress is

\footnotetext{
128. Id.

129. Id.

130. Id.

131. Id..

132. Wiethe v. Beaty, No. CA98-04-049, 1999 WL 74595 at *3 (Ohio Ct. App. Feb. 16, 1999).

133. Id.

134. Id.

135. 385 S.E.2d 384 (W. Va. 1989).

136. Id. at 385 .

137. Id. at 389.

138. See Panossian v. Panossian, 172 A.D.2d 811 (N.Y. App. Div. 1991) (considering an agreement signed two days before the wedding). Other cases have enforced agreements signed shortly before the wedding. See, e.g., Simeone v. Simeone, 581 A.2d 162, 167 (Pa. 1990); Estate of Cooper, 2011 WL 2448979 (Miss. App.); Mann v. Mann, 2010 WL 1266677 at *5 (Ohio Ct. App. Apr. 5, 2010).

139. See Lee v. Lee, 816 S.W.2d 625, 627-28 (Ark. Ct. App. 1991).

140. Cf. Donovan v. Donovan, No. 159622, 1999 WL 1499141 (Va. Cir. Ct.) (making the questionable argument that the objecting party was aware of the "basic parameters" of the agreement to be presented).
} 
customarily defined as "improper and coercive conduct"141 that "destroys the free agency of a party." 142 The case law regarding whether there was duress sufficient to invalidate an agreement is similar to cases discussed above involving whether an agreement was "voluntarily" signed.

Some courts have found duress in fairly extreme situations. For example, in Holler $v$. Holler, ${ }^{143}$ the prospective wife moved from the Ukraine to marry a man in South Carolina. ${ }^{144}$ She had a visa that would expire in three months unless she married. ${ }^{145}$ A month after her arrival she became pregnant by her intended husband. ${ }^{146}$ The groom then gave her a draft of a premarital agreement, which was hard for her to understand because her English was not good. ${ }^{147}$ She did not obtain legal advice before signing the document; they married shortly thereafter, three days before her visa expired. ${ }^{148}$ She could remain in the U.S. only if she married a U.S. citizen. ${ }^{149}$ Because the wife did not understand the agreement, was pregnant, and did not want to return to the Ukraine, the court affirmed the trial court's finding of duress. ${ }^{150}$

Similarly, in Hjortaas v. McCabe, ${ }^{151}$ the man told the woman weeks before the wedding that he wanted a premarital agreement. ${ }^{152}$ He provided a draft of an agreement two or three days before the wedding, and the agreement was signed the day before the wedding. ${ }^{153}$ No financial disclosure was exchanged. ${ }^{154}$ The appellate court concluded that, because she only had "one day to seek counsel ...., to make an independent evaluation of the contract, or to cancel the wedding," her signature was the product of "unwarranted compulsion" and the agreement should not be enforced.155

When an agreement waiving rights is presented at the last minute to a party and that person is told that he or she has to sign it or the wedding will be cancelled, the person waiving rights frequently contends that there was substantial pressure to sign the agreement due to the presence of numerous guests and family members and the embarrassment and expense that would result from canceling the wedding. When considering the issue of duress, although some courts have stated that this concern would be taken seriously if it

141. Francavilla v. Francavilla, 969 So.2d 522, 524-25 (Fla. Dist. Ct. App. 2007).

142. Holler v. Holler, 612 S.E.2d 469, 474 (S.C. Ct. App. 2005). See Howell v. Landry, 386 S.E.2d 610, 616 (N.C. Ct. App. 1989); Schrage v. Schrage, No. 2008-CA-002088-MR, 2009 WL 4882819 (Ky. Ct. App.); Boote v. Shivers, 198 S.W.3d 732, 745 (Tenn. Ct. App. 2005).

143. 612 S.E.2d 469 (S.C. Ct. App. 2005).

144. Id. at 471 .

145. Id.

146. Id.

147. Id.

148. Id.

149. Id.

150. Id. at 476 .

151. 656 So.2d 168 (Fla. Dist. Ct. App. 1995).

152. Id. at 169 .

153. Id.

154. Id.

155. Id. at 170 . 
is a large wedding with many guests, 156 most courts have ruled that, regardless of whether it would have been difficult or embarrassing to cancel, the party chose not to do so and was not forced to sign the agreement. ${ }^{157}$

When analyzing whether duress occurred when an agreement is signed shortly before the wedding, some courts in non-UPAA states distinguish between situations where the parties were negotiating the agreement for a substantial period and those where the agreement is presented at the last minute. ${ }^{158}$

A number of courts have found no duress when the agreement was presented a day or two before the wedding. ${ }^{159}$ For example, in the case In re Marriage of Yannalfo, ${ }^{160}$ the man presented the woman with a draft agreement one day before the wedding and told her he would not marry unless she signed the agreement. ${ }^{161}$ In their later divorce, the trial court invalidated the agreement based on duress. ${ }^{162}$ The New Hampshire Supreme Court reversed, holding that the presentation of an agreement one day before the wedding is "insufficient to support a finding of duress."163

Likewise, in Fletcher $v$. Fletcher, ${ }^{164}$ the court affirmed a trial court finding of no duress when the agreement was presented the day before the wedding. ${ }^{165}$ Similarly, in Williams $v$. Williams, ${ }^{166}$ the court affirmed a finding by the trial court that there was no duress when a premarital agreement was presented and signed a day before the wedding. ${ }^{167}$

156. Compare In re Estate of Hollett, 834 A.2d 348, 350, 353 (N.H. 2003) (emphasizing the large wedding as one factor justifying the ruling that the agreement was involuntarily signed), with Francavilla v. Francavilla, 969 So.2d 522, 525 (Fla. Dist. Ct. App. 2007) (noting the couple planned to marry at the courthouse and that the wedding could have easily been postponed), Fletcher v. Fletcher, 628 N.E.2d 1343, 1347 (Ohio 1994) (noting that the wedding could have been relatively easily been postponed), In re Marriage of Bonds, 5 P.3d 815, 820 (Cal. 2000) (noting the wedding could have easily been postponed), and Millstein v. Millstein, No. 80963,2002 WL 31031676 *8 (Ohio Ct. App. Sept. 12, 2002) (noting the wedding could have easily been postponed).

157. See Brown v. Brown, 26 So.3d 1210, 1217 (Ala. Ct. Civ. App. 2007); DeLorean v. DeLorean, 511 A.2d 1257, 1259 (N.J. Super. Ct. 1986).

158. See Francavilla v. Francavilla, 969 So.2d 522, 525 (Fla. Dist. Ct. App. 2007) (containing a long negotiation period); Boote v. Shivers, 198 S.W.3d 732 (Tenn. App. 2005) (containing a long negotiation period); Simeone v. Simeone, 581 A.2d 162 (Pa. 1990) (finding that the agreement had been negotiated for a long period).

159. See Ware v. Ware, 7 So.3d 271, 276-77 (Miss. Ct. App. 2008) (holding that the waiving party was not forced to sign the agreement presented two days before the wedding); Brown v. Brown, 26 So.3d 1210, 1217 (Ala. Ct. Civ. App. 2007) (emphasizing the objecting party was a real estate agent with experience negotiating contracts); Howell v. Landry, 386 S.E.2d 610, 614-15 (N.C. Ct. App. 1989) (finding that the objecting party "was not compelled by financial or other considerations to marry the next day"); Hood v. Hood, 72 So.3d 666 (Ala. App. 2011).

160. In re Marriage of Yannalfo, 794 A.2d 795 (N.H. 2002).

161. Id. at 796 .

162. Id. at 797 .

163. Id.

164. 628 N.E.2d 1343 (Ohio 1994).

165. Id. at 1348. The court concluded the wedding date could easily have been postponed. $I d$. at 1347.

166. 720 S.W.2d 246 (Tex. App. 1986).

167. The court emphasized that the waiving party had experience with contracts in her job. Id. at 
As stated above, there is a split of authority regarding whether presenting an agreement a day or two before the wedding is duress. ${ }^{168}$ In contrast, agreements presented more than a few days before the wedding are almost always considered to have been negotiated without duress. ${ }^{169}$ An exception is Eyster $v$. Pechenik, ${ }^{170}$ where the court stated that an agreement signed five days before the wedding "raised questions" of duress. ${ }^{171}$

Regardless of whether the court is applying a standard of "involuntariness" or "duress," most courts have not found duress if a woman is pregnant and the man offers to marry her only if she signs a premarital agreement. ${ }^{172}$

\section{ii. Summary}

The discussion above shows that, regardless of whether a state applies a standard of involuntariness, duress, overreaching, coercion, or undue influence, a significant number of courts have enforced premarital agreements proposed at the last minute.

\section{B. Disclosure of Financial Information}

Under the UPAA, it is only relevant whether the waiving party received adequate information from the other if the waiving party can also establish the agreement was unconscionable when signed. ${ }^{173}$ Some "adopting" states modified this provision to be consistent with the approach applied in almost all

248.

168. Compare Hjortaas v. McCabe, 656 So.2d 168 (Fla. Dist. Ct. App. 1995), with In re Marriage of Yannalfo, 794 A.2d 795 (N.H. 2002), Fletcher v. Fletcher, 628 N.E.2d 1343 (Ohio 1994) and Williams v. Williams, 720 S.W.2d 246 (Tex. App. 1986).

169. See, e.g., Francavilla v. Francavilla, 969 So.2d 522, 525 (Fla. Dist. Ct. App. 2007) (noting that the agreement was signed one hour before the ceremony, but the parties had been negotiating "for months" and the waiving party had a lawyer); Millstein v. Millstein, No. 80963, 2002 WL 31031676 at *7-8 (Ohio Ct. App. Sept. 12, 2012) (finding that eight days were sufficient); Gordon v. Gordon, 25 So.3d 615, 617 (Fla. Dist. Ct. App. 2009) (finding that ten days were sufficient); McKee-Johnson v. Johnson, 444 N.W.2d at 262 (finding that ten days were sufficient).

170. 887 N.E.2d 272 (Mass. App. Ct. 2008).

171. Id. at 282 .

172. See Biliouris v. Biliouris, 852 N.E.2d 687 (Mass. App. Ct. 2006) (finding no duress); Francavilla v. Francavilla, 969 So.2d 522 (Fla. Dist. Ct. App. 2007) (finding no duress); In re Marriage of Dawley, 551 P.2d 323 (Cal. 1976) (finding no undue influence); Herrera v. Herrera, 895 So.2d 1171 (Fla. Dist. Ct. App. 2005) (finding no duress); Mallen v. Mallen, 622 S.E.2d 812 (Ga. 2005) (finding no duress); Osorno v. Osorno, 76 S.W.3d 509 (Tex. App. 2002) (finding the agreement was voluntarily signed); Kilborn v. Kilborn, 628 So.2d 884 (Ala. Civ. App. 1993) (finding the agreement was voluntary). But see Rowland v. Rowland, 599 N.E.2d 315 (Ohio Ct. App. 1991); Bassler v. Bassler, 593 A.2d 82 (Vt. 1991). In this regard, courts apparently have been more enthusiastic about enforcing agreements than the drafting committee intended. When the UPAA was being debated, it was suggested that an agreement would not be enforced under the UPAA if a young pregnant girl was asked to sign a one-sided agreement as a condition of marriage. See NATIONAL CONFERENCE OF COMMISSIONERS ON UNIFORM STATE LAWS, PROCEEDINGS IN THE COMMITTEE OF THE WHOLE, UNIFORM PREMARITAl AGREEMENT ACT 71-72 (1983).

173. See Unif. Premarital Agreement Act, \$6, 9C U.L.A. $48-49$ (2001). See Chaplain v. Chaplain, 682 S.E.2d 108, 115 (Va. App. 2009) (finding that the challenging party was able to establish both elements, which is rare in cases). 
other states, namely that insufficient knowledge of the other's financial condition at the time of signing should be an independent ground for invalidating an agreement. ${ }^{174}$ For instance, in Minnesota premarital agreements are to be enforced only if there was "full and fair disclosure of the earnings and property" of each party. ${ }^{175}$

In most UPAA states, the disclosure requirement is satisfied by: (i) disclosure, (ii) the party being aware of the information by other means, or (iii) a waiver of the right to disclosure. Some states do not mention all three of these ways of satisfying the requirement. For example, the Minnesota, Virginia, and Connecticut statutes require disclosure. ${ }^{176}$ The Wisconsin and Iowa statutes do not mention that the right to disclosure can be waived.177

There is widespread disagreement among states regarding the amount of information needed to satisfy the disclosure requirement. For example, in DeLorean v. DeLorean, the waiving party had extremely general knowledge of her prospective husband's finances. ${ }^{178}$ The agreement provided that the "[h]usband is the owner of substantial real and personal property and he has reasonable prospects of earning large sums of monies."179 The wife apparently knew that the husband had an interest in a farm in California, a large tract of land in Montana, and a share of a major league baseball team. ${ }^{180}$ The court concluded that this level of disclosure satisfied what it found to be the less demanding standard applicable in California, but that it did not meet the more rigorous New Jersey standard. ${ }^{181}$

As the DeLorean court noted, states are applying different standards regarding financial disclosure requirements for premarital agreements. ${ }^{182}$ Most states seem to agree that a precise disclosure of the value of all property is not needed; a general and approximate knowledge appears sufficient. ${ }^{183}$ But what does this mean in practice? In one case, ${ }^{184}$ the wealthy party did not disclose his income. ${ }^{185}$ Was this material? The court held that it was not, at least in part because the woman knew he was wealthy with significant income-producing assets, and she had lived with him for four years before the agreement was

\footnotetext{
174. See supra Part II. B. iv.

175. See MinN. STAT. ANN. § 519.11 (West 2006).

176. See id.; CONN. GEN. STAT. § 46(b)-36(g) (West 2009); VA. CODE ANN. § 20-151 (2008).

177. See Wis. STAT. ANN. § 766.58 (West 2008); IOWA CODE ANN. § 596.8 (West 2011).

178. 511 A.2d 1257 (N.J. Super. Ct. Ch. Div. 1986).

179. Id. at 1260 .

180. Id.

181. The court enforced the agreement because it found California law should govern. Id.

182. See id.

183. See Robinson v. Robinson, 64 So.3d 1067 (Ala. Civ. App. 2010); Gordon v. Gordon, 25 So.3d 615 (Fla. Dist. Ct. App. 2009); Brown v. Brown, 26 So.3d 1210 (Ala. Civ. App. 2007); In re Estate of Davis, 213 S.W.3d 288 (Tenn. Ct. App. 2006); Cannon v. Cannon, 865 A.2d 563 (Md. 2005); Millstein v. Millstein, No. 80963, 2002 WL 310311676 (Ohio Ct. App. Sept. 12, 2002); Griffin v. Griffin, 94 P.3d 96 (Okla. Civ. App. 2004); Marriage of Spiegel, 553 N.W.2d 309 (Iowa 1996).

184. Dove v. Dove, 680 S.E.2d 839 (Ga. 2009).

185. Id. at 843 .
} 
signed. ${ }^{186}$ In Corbett $v$. Corbett, 187 the same court held that, where the agreement contained an alimony waiver and the objecting party was not otherwise aware of the man's income, the wealthy person's nondisclosure of his income was grounds for invalidating the agreement. 188 In other cases, the nondisclosure of significant premarital savings was sufficient to invalidate the agreement. ${ }^{189}$

Other cases consider whether it is sufficient that the objecting party knew what the other party owned or whether an approximate value also needs to be provided. The court in Gordon v. Gordon ${ }^{190}$ held that omitting the husband's rights to a pension plan from his disclosure statement did not invalidate the agreement where the woman had a "general and approximate" knowledge of the husband's resources. ${ }^{191}$ In a North Dakota case, it was considered sufficient that the waiving party knew her prospective husband "was worth a substantial amount of money." 192 One court has concluded that, when parties marry early in their adult life with few assets, a lack of disclosure of financial information should not be grounds for invalidating an agreement. ${ }^{193}$ A number of courts have held that the waiving party has adequate familiarity with the other party's financial situation if they dated a substantial period of time before the wedding and thereby became knowledgeable of the other's standard of living and spending habits. ${ }^{194}$ In cases where the assets were identified but no values were set forth, it could be important whether the assets would be easy to value (such as publicly traded stocks) or the objecting party was familiar with the assets. ${ }^{195}$

Some states, including Tennessee, appear to require more detailed disclosures. ${ }^{196}$ In In re Estate of Davis, 197 the husband was aware when he signed the agreement that the wife had a contract with a recording company and that

186. See id. See also Mallen v. Mallen, 622 S.E.2d 812, 816 (Ga. 2005) (finding that the woman had an awareness of the man's "significant income."); Smith v. Walsh-Smith, 66 A.D.3d 534, 535 (N.Y. Sup. Ct. 2009) (finding disclosure of the wealthy party's income was not needed where the other party was fully aware of the financial disparity between the two parties); Lawrence v. Lawrence, 687 S.E.2d 421, 425 (Ga. 2009) (finding disclosure of the wealthy party's income was not needed where the other party was fully aware of the financial disparity between the two parties).

187. 628 S.E.2d 585 (Ga. 2006).

188. See id. Other courts have held the disclosure incomplete when the party's income was not disclosed. See Casto v. Casto, 508 So.2d 330 (Fla. 1987); Stemler v. Stemler, 36 So.3d 54 (Ala. Civ. App. 2009) (applying Florida law).

189. See Alexander v. Alexander, 610 S.E.2d 48, 49-50 (Ga. 2005) (noting a \$40,000 account); Blige v. Blige, 656 S.E.2d 822, 825-26 (Ga. 2008) (noting \$150,000 in hidden cash).

190. 25 So.3d 615 (Fla. Dist. Ct. App. 2009).

191. Id. at 618 .

192. Binek v. Binek, 673 N.W.2d 594, 599 (N.D. 2004). See also, Brown v. Brown, 26 So.3d 1210 (Ala. Civ. App. 2007) (finding waiving spouse was aware the other party "was a millionaire").

193. See Reed v. Reed, 693 N.W.2d 825 (Mich. Ct. App. 2005).

194. See Winchester v. McCue, 882 A.2d 143, 147-48 (Conn. App. Ct. 2005) (noting that the waiving party was a lawyer who was represented by independent counsel.); Donovan v. Donovan, No. 159622, 1999 WL 1499141 at *5 (Va. Cir. Ct. Sept. 28, 1999) (noting that the waiving party helped the other maintain records of his various businesses).

195. See In re Estate of Reinsmidt, 897 S.W.2d 73 (Mo. Ct. App. 1995); Lawrence v. Lawrence, 687 S.E.2d 421 (Ga. 2009).

196. See In re Estate of Davis, 213 S.W.3d 288 (Tenn. Ct. App. 2006).

197. 213 S.W.3d 288 (Tenn. Ct. App. 2006). 
she owned some other property. ${ }^{198}$ The value of the properties was not disclosed, and the court found that he was not otherwise aware of their value. ${ }^{199}$ Because the husband was not aware of the value of her properties, the agreement was not enforced. 200

In these types of cases in Tennessee, it may become determinative whether the objecting spouse had independent counsel. In Reece v. Elliott, ${ }^{201}$ the issue was similar to that presented in In re Estate of Davis. ${ }^{202}$ The disclosure document listed various assets but did not list approximate values for all.203 The appellate court affirmed the finding that the disclosure was adequate, noting that the objecting party was represented by counsel and that she and her lawyer had the opportunity to ask questions about the financial disclosure document. ${ }^{204}$

New Jersey also requires more detailed disclosure.205 The waiving party must have "full awareness" of the income and assets of the other. ${ }^{206}$ In one case, while the objecting party was aware that the other was a man of some wealth, she had no idea what his net worth was when the agreement was signed, and the agreement was not enforced.207 In Estate of Shinn ${ }^{208}$ the appellate court invalidated the agreement when it found the proponent of the agreement failed to disclose important assets. 209

If disclosure is not made, the agreement will generally not be enforced ${ }^{210}$ unless the objecting party already was aware of the financial information. Also, if the wealthy party materially misrepresents his net worth, this has been held to be inadequate disclosure. For example, in one case, an agreement was invalidated where a party represented in a premarital agreement that his net worth was $\$ 473,000$ but had a few months earlier in a loan application stated his net worth was $\$ 1,341,000 .^{211}$

If a party does attempt to place values on items of property, this presents the issue of how accurate the values need to be. In one case, the wealthy party disclosed that he had an ownership interest in a small business and listed the value as about $\$ 2,000,000 .^{212}$ A footnote stated this was the "book value" of the stock and that the market value could be substantially higher. ${ }^{213}$ The court

198. Id. at 293-94.

199. Id. at 297-98.

200. Id. at 298 .

201. 208 S.W.3d 419 (Tenn. Ct. App. 2006).

202. See 213 S.W.3d 288 (Tenn. Ct. App. 2006).

203. Reece, 208 S.W.3d at 420.

204. Id. at 423 .

205. See Marschall v. Marschall, 477 A.2d 833, 840 ( N.J. Super. Ct. 1984).

206. See id.

207. See Orgler v. Orgler, 568 A.2d 67 (N.J. 1989) (invalidating the agreement even though the objecting party met briefly with a lawyer).

208. 925 A.2d 88 (N.J. App. Div. 2007).

209. Id. at 91.

210. See In re Marriage of Seewald, 22 P.3d 580, 585 (Colo. App. 2001).

211. See Peters-Riemers v. Riemers, 644 N.W.2d 197 (N.D. 2002).

212. Gardner v. Gardner, 527 N.W.2d 701, 705-06 (Wis. Ct. App. 1994).

213. Id. at 705 . 
rejected the waiving party's later argument that providing book value and not market value was misleading, at least in part because the waiving party had a lawyer (who presumably could have requested more detailed financial information). ${ }^{214}$

\section{Independent Counsel}

Although in many states it is important that parties have an opportunity to consult with independent counsel if they so choose, in no state is consultation with independent counsel a requirement for an enforceable premarital agreement. ${ }^{215}$ The presence of independent counsel is a factor courts consider when deciding questions of voluntary execution or the adequacy of financial disclosure. ${ }^{216}$ The West Virginia Supreme Court recently announced that a premarital agreement will be presumed valid only if both parties consulted with independent counsel. ${ }^{217}$ In California, a restriction on spousal support is permissible only if the waiving party consulted with independent counsel. ${ }^{218}$

\section{JUDICIAL REVIEW OF SUBSTANTIVE FAIRNESS}

Premarital agreements contemplating divorce normally attempt to alter the economic rights of the parties if they divorce. Some limit the rights of the less wealthy spouse but still provide significant financial recovery to that spouse if the marriage ends in divorce. ${ }^{219}$ But many severely restrict or attempt to completely eliminate all financial claims upon divorce. 220

States disagree regarding the extent to which the substantive fairness of an agreement should impact its enforceability. Under the UPAA, substantive fairness is relevant only if there is also inadequate financial disclosure. ${ }^{221}$ In many non-UPAA states, an agreement may be challenged based upon unfairness

214. Id. at 706 .

215. See Binek v. Binek, 673 N.W.2d 594 (N.D. 2004); Peters-Riemers v. Riemers, 644 N.W.2d 197 (N.D. 2002); In re Marriage of Bonds, 5 P.3d 815 (2000); In re Marriage of Shanks, 758 N.W.2d 506 (Iowa 2008); Mabus v. Mabus, 890 So.2d 806 (Miss. 2003); Simeone v. Simeone, 581 A.2d 162 (Pa. 1990); Donovan v. Donovan, No. 159622, 1999 WL 1499141 (Va. Cir. Ct. Sept. 28, 1999); Panossian v. Panossian, 172 A.D.2d 811 (N.Y. App. Div. 1991); In re Estate of Lutz, 563 N.W.3d 90 (N.D. 1997); Fletcher v. Fletcher, 628 N.E.2d 1343 (Ohio 1994); In re Estate of Kinney, 733 N.W.2d 118 (Minn. 2007); Brown v. Brown, 26 So.3d 1210 (Ala. Civ. App. 2007). See generally OldHAM, DivORCE, SEPARATION, supra note 47 , at $\S 4.03[5]$ nn.96, 99, \& 104 ..

216. See, e.g., Randolph v. Randolph, 937 S.W.2d 815 (Tenn. 1996); In re Estate of Smid, 756 N.W.2d 1 (S.D. 2008); In re Estate of Lutz, 563 N.W.2d 90 (N.D. 1997); Fletcher v. Fletcher, 628 N.E.2d 1343 (Ohio 1994); Holler v. Holler, 612 S.E.2d 469 (S.C. Ct. App. 2005); Edwards v. Edwards, 744 N.W.2d 243 (Neb. 2008); In re Estate of Kinney, 733 N.W.2d 118 (Minn. 2007); Ansin v. Craven-Ansin, 929 N.E.2d 955, 963 n.9 (Mass. 2010). See generally OLDHAM, DIVORCE, SEPARATION, supra note 47, at § 4.03[5], n.97.

217. See Ware v. Ware, 687 S.E.2d 382, 390-91 (W.Va. 2009).

218. See CAL. FAM. CODE $\S 1612$ (c) (West 2004).

219. See Jamie Doward, Divorce Deals: Wealthy, Young British Men Turn to Prenups, THE OBSERVER, July 18, 2010 (describing the premarital agreement between Tom Cruise and Katie Holmes).

220. See id.

221. See supra Part II. B. iv. See, e.g., Tex. Fam. Code $\S 4.006(a)(2)$. 
alone.222 Some states evaluate fairness at the time of signing and some at the time of enforcement. ${ }^{223}$ A few consider whether the agreement is fair; ${ }^{224}$ most consider whether it is unconscionable.225 Others ask whether the parties' circumstances have changed in an unforeseeable way during the marriage.226

\section{A. Unconscionability}

In some states that adopted the bulk of the UPAA, an agreement can be challenged solely based on the unconscionability of the agreement. In Wisconsin, Indiana, and Nevada, the focus is on unconscionability at time of signing. 227 Connecticut, New Jersey, and North Dakota consider unconscionability at the time of enforcement. ${ }^{228}$ Other non-UPAA courts also review for unconscionability at the time of divorce. ${ }^{229}$

Few statutes define what constitutes an unconscionable agreement. The New Jersey statute provides that an agreement is unconscionable if it leaves a party without a means of reasonable support or would provide a standard of living for a party far below what the party enjoyed before the marriage. ${ }^{230}$

In states without statutory definitions, courts must clarify the characteristics of an unconscionable agreement. A few courts have stated that an unconscionable agreement is one that is not "fair, reasonable and just."231 Most courts require a more substantial showing to find an agreement unconscionable. One court noted that review of an agreement for unconscionability "is substantially more circumscribed than review for mere inequity," 232 and courts are to examine factors of "unfair surprise, notice, disparity of bargaining power, and substantive unfairness." 233 Another court suggested that the primary focus should be whether there was unfair surprise and the extent to which the agreement is one-sided.234 Another perspective is that "[u]nconscionability is the absence of meaningful choice on the part of one party due to one-sided contract provisions, together with terms which are so oppressive that no reasonable person would make [these provisions]."235 Other courts have characterized an

222. See OldHAM, DivORCE, SEPARATION supra note 47, at $\S 4.03$ [3].

223. See supra Part II. B. i.

224. See DeMatteo v. DeMatteo, 762 N.E.2d 797 (Mass. 2002) (stating an agreement must be "fair and reasonable" when signed).

225. See infra Part IV. A.

226. See id.

227. See Wis. StAT. ANN. § 766.58(6) (West 2009); IND. CODE 31-11-3-8 (LexisNexis 2007); NeV. REV.STAT. ANN. § 123 A.080(1) (LexisNexis 2010).

228. See CONN. GEN. StAT. ANN. § 46b-36g (West 2009); N.J. STAT. ANN. § 37:2-37 (West 2011); N.D. CENT. CODE § 14-03.1-07 (2009).

229. See Blue v. Blue, 60 S.W.3d 585, 590 (Ky. Ct. App. 2001); DeMatteo v. DeMatteo, 762 N.E.2d 797 (Mass. 2002) (stating that an agreement must also be "fair and reasonable" when signed).

230. See N.J. STAT. ANN. §37:2-32.

231. See In re Marriage of Christen, 899 P.2d 339, 343 (Colo. App. 1995).

232. In re Marriage of Shanks, 758 N.W.2d 506, 514-15 (Iowa 2008).

233. Id.

234. See Lewis v. Lewis, 748 P.2d 1362 (Haw. 1988).

235. See Holler v. Holler 612 S.E.2d 469, 476 (S.C. Ct. App. 2005). See also Chaplain v. Chaplain, 
unconscionable agreement as one where the inequity is "strong, gross and manifest,"236 the terms are "manifestly unfair and unreasonable,"237 or enforcement of the agreement would "work an injustice." 238

But what do these terms mean in practice? In Gentry v. Gentry, 239 the court held that the agreement should not be enforced if a party would thereby be unable to be self-supporting after divorce. ${ }^{240}$ Other courts have held that an agreement should not be enforced if a party would become a public charge. ${ }^{241} \mathrm{~A}$ third view is that the relevant inquiry looks to whether the parties' circumstances have changed in an unforeseeable way since the wedding. ${ }^{242}$ One court held an agreement to be unconscionable where the waiving party had no assets and no income. ${ }^{243}$

For example, the Connecticut Supreme Court has held that a postnuptial agreement should not be enforced if it would be unconscionable at divorce to do so. In Bedrick v. Bedrick, ${ }^{244}$ the parties signed a postnuptial agreement in 1977 and amended it in 1989.245 The amended agreement limited the wife's claims at divorce to a payment of $\$ 75,000.246$ In 2007 , the wife filed for divorce. 247 The Connecticut Supreme Court affirmed the trial court's finding that the agreement should not be enforced because doing so would work an injustice. ${ }^{248}$ The Connecticut Supreme Court noted that "[u]nforeseen changes in the relationship, such as having a child, loss of employment or moving to another state, may render enforcement of an agreement unconscionable."249 In this case, after the agreement had been amended, the wife gave birth to a child and the husband's financial situation changed significantly. ${ }^{250}$

An alternative standard for reviewing a premarital agreement is that an agreement should not be enforced if it would leave either party with a standard of living far below that enjoyed before or during marriage. ${ }^{251}$ Another suggested standard is that an agreement is not unconscionable at divorce if it does not attempt to restrict spousal support. ${ }^{252}$ In evaluating the conscionability of an

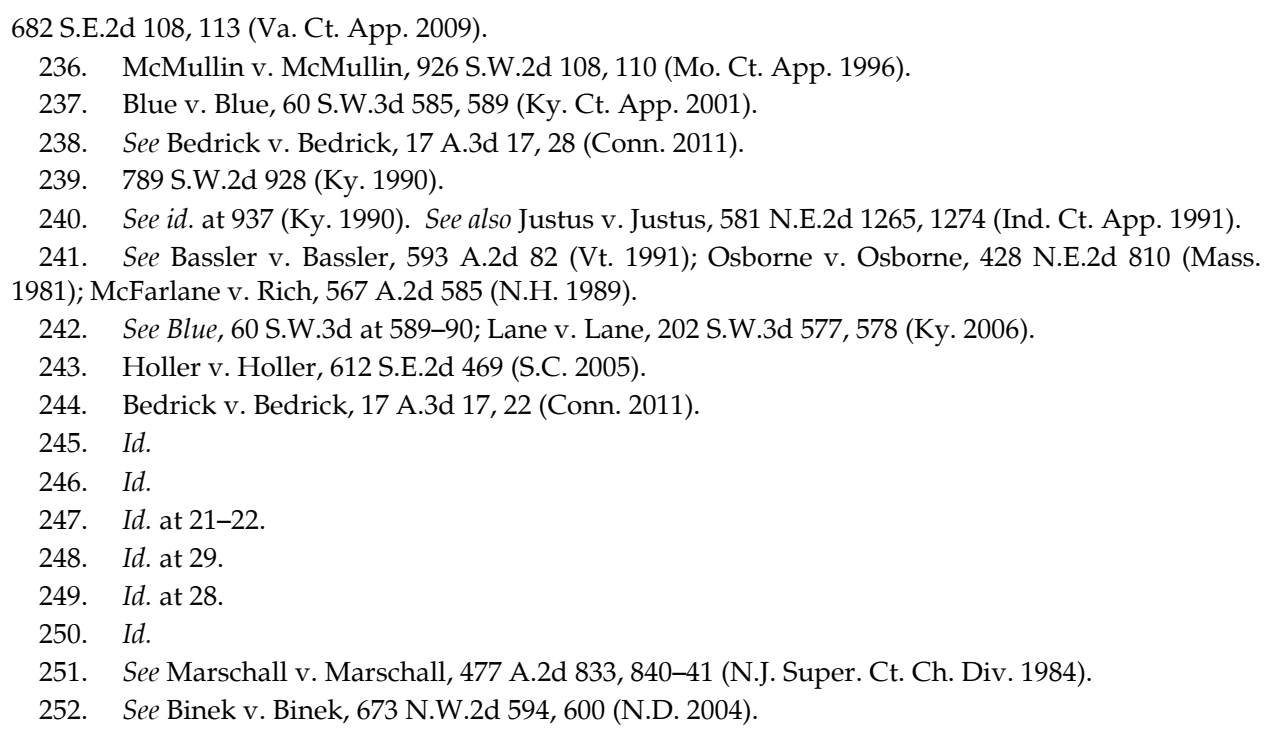


agreement, some courts have considered whether the party waives all rights to the possibility of a divisible marital estate. ${ }^{253}$

The terms of the agreement, the age of the parties, and their respective roles during the marriage also can be relevant in determining unconscionability. In Lane $v$. Lane, ${ }^{254}$ the court emphasized that the agreement involved both a waiver of the right to divide a marital estate at divorce as well as the right to postdivorce maintenance. ${ }^{255}$ This court also suggested that agreements between spouses marrying later in life were more likely to be upheld than agreements between younger parties who had children together. ${ }^{256}$

Courts are not limited to choosing between fully enforcing or invalidating an agreement. They might choose to enforce a portion and invalidate a portion. In Lane, for example, both parties waived their rights to equitable distribution as well as their rights to maintenance. ${ }^{257}$ During marriage, the husband's career prospered and the wife stayed home to take care of their young children. ${ }^{258}$ After ten years of marriage, the husband filed for divorce. 259 The trial court enforced the waiver of equitable distribution but found that enforcement of the maintenance waiver would be unconscionable, ordering the husband to pay $\$ 12,000$ monthly for three years. ${ }^{260}$ The Kentucky Supreme Court held that a court may decide not to enforce some or all of a premarital agreement when at the time of divorce circumstances had changed since the agreement was signed so as to make enforcement unfair and unreasonable. ${ }^{261}$ The husband's annual earnings had increased during marriage from $\$ 166,000$ to $\$ 1,000,000 .{ }^{262}$ The Kentucky Supreme Court affirmed the trial court's holding that the waiver of the right to equitable distribution should be enforced but the waiver of maintenance should not.263 Similarly, a number of courts have proposed that waivers of the right to equitable distribution should be presumptively valid, but if there is also a waiver of spousal support the court should more aggressively review whether the enforcement of a waiver of the right to support would be unfair. ${ }^{264}$

Likewise, in a recent New Jersey case, Rogers $v$. Gordon, 265 the parties

253. See Miles v. Werle, 977 S.W.2d 297 (Mo. Ct. App. 1998); In re Marriage of Thomas, 199 S.W.3d 847 (Mo. Ct. App. 2006).

254. 202 S.W.3d 577 (Ky. 2006).

255. Id. at 579-80.

256. Id. at 580 .

257. Id. at 578 .

258. Id.

259. Id.

260. Id. at 579 .

261. Id.

262. Id.

263. Id. at 581 .

264. See Lewis v. Lewis, 748 P.2d 1362 (Haw. 1988); Newman v. Newman, 653 P.2d 728 (Colo. 1982). Lewis has been superseded by statute. In In re Marriage of Dechant, the court construed CoLO. REV. STAT. § 14-2-307 (2011) as a codification of the Newman approach. 867 P.2d 193 (Colo. App. 1993),

265. 961 A.2d 11 (N.J. Super. Ct. 2008). 
married at a relatively young age with few assets. ${ }^{266}$ However, different career trajectories seemed quite likely. The husband worked for the postal service while the wife had graduated from Princeton and was planning to pursue an MBA at the Wharton School. ${ }^{267}$ Their premarital agreement apparently included waivers of the right to equitable distribution and the right to support. ${ }^{268}$ After a twenty-four-year marriage, the wife was earning \$578,000 annually and the husband's annual income of $\$ 63,000$ seemed likely to decrease in the future.269 The appellate court enforced the waiver of a right to equitable distribution but would permit spousal support if the husband would otherwise have a standard of living lower than that enjoyed during marriage. ${ }^{270}$

Other courts have agreed that changes in the parties' circumstances during marriage should be more relevant to restrictions on spousal support than waivers relating to equitable distribution. ${ }^{271}$ For example, the Colorado Supreme Court proposed that, while equitable distribution waivers should not be subject to a fairness review, a restriction on the right to spousal support could be unconscionable and should not be enforced if it would leave a party after divorce "without a means of reasonable support."272 The Hawaii Supreme Court proposed a similar approach. ${ }^{273}$

This approach was also applied in Gross v. Gross ${ }^{274}$ where the parties signed a premarital agreement which waived the right to equitable distribution and provided that, in the event of a divorce, the husband would pay the wife monthly spousal support of $\$ 200$ for ten years. 275 The parties divorced twelve years later when the husband's net worth had quite substantially increased to $\$ 6,000,000$ and his income had also significantly increased. ${ }^{276}$ The court adopted an approach similar to that applied by the Colorado Supreme Court in Newman ${ }^{277}$ : a waiver of the right to property division should not be subject to a substantive fairness review, but a restriction on the right to spousal support can become unconscionable if circumstances of the parties have significantly changed during marriage. ${ }^{278}$ Here the court ruled that, in light of the substantial increase in the husband's wealth during marriage, it would be unconscionable to enforce the maintenance restriction. ${ }^{279}$

\footnotetext{
266. See id. at 13 .

267. Id.

268. Id. at 20 .

269. Id. at 14 .

270. Id. at 21.

271. See Lewis v. Lewis, 748 P.2d 1362 (Haw. 1988); Newman v. Newman, 653 P.2d 728 (Colo. 1982).

272. Newman, 653 P.2d at 736.

273. Lewis, 748 P.2d at $1366-67$.

274. 464 N.E.2d 500 (Ohio 1984).

275. Id. at 503 .

276. Id.

277. See Newman, 653 P.2d 728.

278. Gross, 464 N.E.2d at 509.

279. On remand, the wife was awarded monthly support in the amount of $\$ 2,500$ for an indefinite period. Gross, 492 N.E.2d 476 (Ohio Ct. App. 1985). For an Ohio case finding an alimony
} 


\section{B. Substantial and Unforeseen Change in Circumstances}

In reviewing the fairness of an agreement at divorce, some courts have decided that an agreement should not be enforced if the circumstances of the parties changed during marriage in ways that were beyond the contemplation of the parties when they married. ${ }^{280}$ In one case, the waiving party suffered years of domestic violence during the marriage and the husband insisted she quit her job; this was found to be an unforeseen change in circumstances. 281 The Wisconsin Supreme Court has suggested that an unforeseen health problem or an unplanned pregnancy could be an unforeseen change in circumstances that would justify not enforcing the agreement. ${ }^{282}$ In many instances, however, the change in the parties' circumstances has been perceived to be foreseeable.

For example, in Winchester v. McCue, ${ }^{283}$ the parties filed for divorce after fifteen years of marriage. ${ }^{284}$ Their premarital agreement apparently barred the division of marital property or the award of spousal support. 285 The husband's net worth was $\$ 1,223,000$ when the marriage began and increased by more than $400 \%$ during marriage. ${ }^{286}$ The court found that this was not an "extraordinary change in economic status" that was "so far beyond the contemplation of the parties ... a as to make enforcement of the agreement work an injustice." 287

A similar outcome was reached in Crews $v$. Crews ${ }^{288}$ where the parties divorced after seventeen years of marriage. ${ }^{289}$ The parties had raised children together. ${ }^{290}$ The wife had been in a car accident, which limited her mobility. ${ }^{291}$ The premarital agreement apparently banned both equitable distribution of property as well as the right to spousal support. ${ }^{292}$ The trial court concluded that, because the value of the husband's assets had greatly increased during marriage and in light of the length of the marriage and the wife's homemaking contributions, the agreement should not be enforced. ${ }^{293}$ On appeal, the Connecticut Supreme Court noted the approach taken in Winchester v. McCue that an agreement should be considered unenforceable only upon a showing of

waiver not unconscionable, see Mann v. Mann, No. 09CA009685, 2010 WL 1266688 at *4 (Ohio Ct. App. Apr. 5, 2010).

280. See, e.g., MacFarlane v. Rich, 567 A.2d 585 (N.H. 1989). See also Reed v. Reed, 265 Mich. App. 131, 693 N.W.2d 825 (2005); Mazzitelli v. Mazzitelli, 2005 WL 221683 (Minn. App.); Warren v. Warren, 147 Wis.2d 704, 433 N.W.2d 295 (1988); Gant v. Gant, 329 S.E.2d 106 (W. Va. 1985).

281. See Hutchison v. Hutchison, No. 284259, 2009 WL 2244522 at *3-4 (Mich. Ct. App. July 28, 2009).

282. See Warren v. Warren, 433 N.W.2d 295 (Wis. 1988).

283. 882 A.2d 143 (Conn. App. Ct. 2005).

284. Id. at 146 .

285. Id. at 145 .

286. Id. at $145,149$.

287. Id. at 149 (quoting McHugh v. McHugh, 436 A.2d 8, 12 (Conn. 1980)).

288. 989 A.2d 1060 (Conn. 2010).

289. Id. at $1062-63$.

290. Id. at 1062 .

291. Id. at 1063.

292. Id. at 1067-68.

293. Id. at 1070. 
an "extraordinary change in economic status."294 The Supreme Court affirmed the appellate court's ruling that the changes in the parties' circumstances were consistent with the parties' expectations when they married because the premarital agreement contemplated that the parties would raise children together. 295

In a Georgia case involving a similar issue, the parties signed a premarital agreement that barred the division of marital property and set forth a specified formula for alimony. ${ }^{296}$ At the time of execution, the wife's net worth was $\$ 10,000$ and the husband's was $\$ 8,500,000 .{ }^{297}$ The parties had four children during the marriage. ${ }^{298}$ After eighteen years of marriage, the husband, whose net worth had increased to $\$ 22,700,000$, filed for divorce.299 The trial court enforced the agreement, whereby the wife was to receive $\$ 2,900$ in monthly alimony for four years. ${ }^{300}$ The Georgia Supreme Court affirmed the trial court's ruling, emphasizing that it was not unforeseeable that the husband's assets would grow in value significantly. ${ }^{301}$

A different conclusion was reached in Mazzitelli v. Mazzitelli. ${ }^{302}$ In this case, the parties had contemplated having children when they married, but the wife contended she had assumed she would take a short break from her career to have a child and then resume her career. ${ }^{303}$ Instead, she stopped working outside the home for almost ten years to raise the parties' children. ${ }^{304}$ The appellate court affirmed the ruling of the trial court that the agreement should not be enforced based on the change in the parties' circumstances. ${ }^{305}$

Finally, in a South Carolina case analyzing the foreseeability of changed circumstances, 306 the wife had various health problems when the parties married. ${ }^{307}$ At the time of divorce, her health problems had become more severe and she was totally disabled. ${ }^{308}$ The South Carolina Supreme Court found this result foreseeable and enforced the agreement. ${ }^{309}$

294. Winchester v. McCue, 882 A.2d 143 at 149.

295. Crews, 989 A.2d at 1071-72. Reed v. Reed is another case involving a long marriage where the parties had signed a premarital agreement and the appellate court ruled that it was foreseeable that over the course of a marriage of twenty-six years each party might accumulate substantially different amounts of assets, so the agreement was enforced. 693 N.W.2d 825 (Mich. Ct. App. 2005).

296. Mallen v. Mallen, 622 S.E.2d 812, 814 (Ga. 2005).

297. Id.

298. Id.

299. Id.

300. Id.

301. See also Reed v. Reed, 693 N.W.2d 825 (Mich. Ct. App. 2005) (holding that a substantial increase in value of a party's assets during a lengthy marriage was foreseeable).

302. 2005 WL 221683 (Minn. App. 2005).

303. Id. at $* 2$.

304. Id.

305. Id. at *3. See also Bedrick v. Bedrick, 17 A.3d 17 (Conn. 2011) (holding that the parties' marital agreement was unconscionable due to changed circumstances).

306. Hardee v. Hardee, 585 S.E.2d 501 (S.C. 2003).

307. Id. at 502 .

308. Id.

309. Id. at 505 . 
Within the past decade, while a few courts have invalidated an agreement based on changed circumstances, a number of courts have ruled that various changes in the circumstances of the parties, regardless of whether they were substantial, were foreseeable at the time of execution and therefore were not grounds for invalidating the agreement.

\section{Restrictions Upon the Right to Spousal Support}

Under the UPAA, spousal support waivers generally are enforced unless the waiving party would become a public charge after divorce. 310 Furthermore, a few non-UPAA states have enforced a spousal support waiver even when the waiving spouse would become a public charge if it was foreseeable that this could occur when the agreement was signed. 311

In contrast, some states do not permit a restriction of the right to spousal support in a premarital agreement. ${ }^{312}$ In other states, courts sometimes have found a waiver of the right to spousal support to be unconscionable at the time of divorce and therefore unenforceable. ${ }^{313}$

For example, one court stated that a contractual restriction on alimony should not be enforced if the waiving party will not be able to provide for his or her reasonable post-divorce needs. ${ }^{314}$ Another view is that, if the waiving party would thereby experience a substantial change in circumstances from the marital standard of living after divorce, the agreement should not be enforced. ${ }^{315} \mathrm{~A}$ few states have adopted a rule that a contractual restriction of spousal support should not be enforced if it would be unconscionable to do so. ${ }^{316}$ The Illinois statute provides that if a contractual restriction on the right to spousal support would cause a spouse "undue hardship in light of circumstances not reasonably foreseeable at the time of execution[,] ... a court ... may require the other party to provide support to the extent necessary to avoid such hardship."317 In one Illinois case, the parties were married for eight years and had no children. ${ }^{318}$ The parties' incomes at divorce were very different. ${ }^{319}$ The parties, represented by independent counsel, had signed a premarital agreement containing a waiver of

310. See Unif. Premarital Agreement ACt, §6, 9C U.L.A. $48-49$ (2001). See also, Cron v. Cron, 8 A.D.3d 186 (App. Div. 2004).

311. See Hardee v. Hardee, 585 S.E.2d 501, 505 (S.C. 2003); Baker v. Baker, 622 So.2d 541, 543-44

(Fla. Dist. Ct. App. 1993).

312. See supra Part II. B. 3.

313. See DeMatteo v. DeMatteo, 762 N.E.2d 797 (Mass. 2002) (stating that spousal support waivers would not be enforced).

314. See In re Marriage of Dechant, 867 P.2d 193 (Colo. App. 1993).

315. See Rogers v. Gordon, 961 A.2d 11, 20-21 ( N.J. Super. Ct. 2008); Warren v. Warren, 523 N.E. 680, 683 (1988) (stating that a total waiver of maintenance was not fair or reasonable); Upham v. Upham, 630 N.E.2d 307, 310-11 (Mass. App. Ct. 1994) (stating that a complete waiver of maintenance was not fair or reasonable).

316. See COlO. Rev. Stat. ANN. § 14-2-307(2) (West 2011); CAL. FAM. CodE § 1612(c) (West 2004).

317. 750 ILl. COMP. STAT. 10/7(b) (West 2009).

318. In re Marriage of Barnes, 755 N.E.2d 522, (Ill. App. Ct. 2001).

319. See id. at 524 . 
spousal support. 320 The court found that a transition from a "lifestyle of luxury" to a $\$ 24,000$ annual salary after divorce was not an undue hardship. ${ }^{321}$

Likewise, in Indiana, if a contractual restriction on the right to spousal maintenance causes "extreme hardship under circumstances not reasonably foreseeable at the time of execution[,] . . . a court ... may require the other party to provide spousal maintenance to the extent necessary to avoid extreme hardship." 322 In one Indiana case, the parties were married for four years and had no children. ${ }^{323}$ Before they married, they signed a premarital agreement waiving, among other things, a claim for maintenance. ${ }^{324}$ In this case there was testimony that the husband's annual income exceeded $\$ 200,000$, that the wife was "never allowed to work after [marriage]," and that, after the separation, the wife was then earning twenty-five dollars per hour. ${ }^{325}$ Here, the appellate court affirmed the trial court's finding that the enforcement of the maintenance waiver would present an extreme hardship to the wife. ${ }^{326}$

\section{A COMPARATIVE VIEW}

\section{A. England}

England has not passed legislation clarifying when marital agreements contemplating divorce will be enforced. However, recent judicial decisions have changed the ground rules so it now appears more likely that such agreements will be enforced.

MacLeod v. MacLeod 327 involved an American couple who married in Florida. ${ }^{328}$ They moved to the Isle of Man where they signed a postnuptial agreement. ${ }^{329}$ Both parties had independent counsel. ${ }^{330}$ In their later divorce, the English appellate court held that postnuptial agreements generally should be enforced unless a change in the parties' circumstances would make enforcement of the contract "manifestly unjust." 331

A 2010 case appears to accept the validity of prenuptial agreements. ${ }^{332}$ In Radmacher v. Granatino, 333 the English Supreme Court announced the principle that prenuptial agreements should be enforced if they are fair. ${ }^{334}$ The English

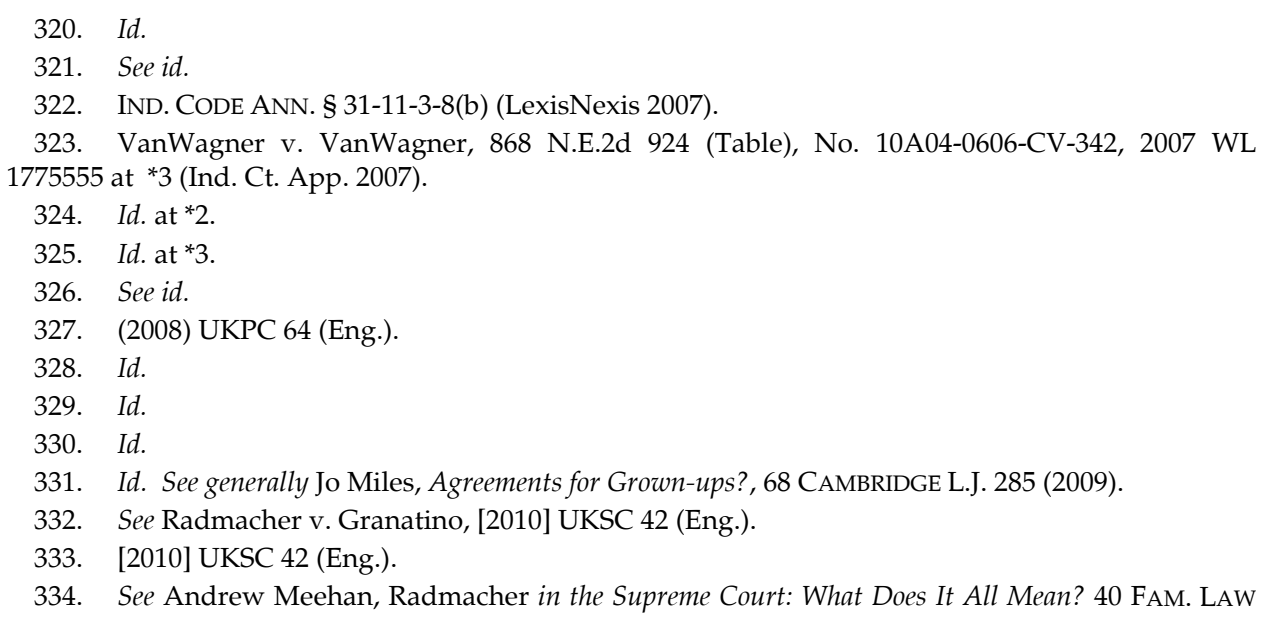


court then set forth some general guidelines regarding when premarital agreements should be enforced. ${ }^{335}$ In terms of procedural requirements, the court stated that an enforceable agreement was one entered into without undue influence where the parties were informed of its implications. ${ }^{336}$ Regarding substantive fairness, the court outlined that trial courts should consider whether the parties' circumstances had changed in unforeseen ways since the agreement was signed. 337

The recent English decisions make it more likely marital agreements will be enforced in English divorces but do not clarify in great detail when equitable concerns will cause courts to invalidate agreements.

\section{B. New Zealand}

New Zealand has a statute dealing with the enforcement of premarital agreements. ${ }^{338}$ What might be most surprising to American readers is that, among other formalities, to create an enforceable agreement each party must receive independent legal advice. ${ }^{339}$ In addition, an agreement can be set aside if enforcement would cause a "serious injustice," 340 a higher standard than mere unfairness. ${ }^{341}$ In deciding whether there would be a serious injustice, the statute directs courts to consider, among other things, the length of time since the agreement was made, whether the agreement was unfair or unreasonable when signed, and whether the agreement has become unfair or unreasonable in light of changes in circumstances since the date of execution. ${ }^{342}$

\section{Australia}

Australia has also legislated standards for prenuptial agreements contemplating divorce. Like New Zealand, the original statute, adopted in 2000, mandated independent representation as a precondition for an enforceable agreement. ${ }^{343}$ Such agreements may address both property division and spousal

1284 (2010); David Hodson, English Marital Agreements for International Families after Radmacher, 2011 INT'L FAM. LAW 31 (2011); Julia Werdigier, Supreme Court in Britain Gives More Legal Force to Prenuptial Agreements, N.Y. TIMES, Oct. 20, 2010, at A9, available at http://www.nytimes.com/2010/10/21/ world/europe/21divorce.html.

335. Id.

336. See Nina Dethloff, Contracting in Family Law: A European Perspective, in THE FUTURE OF FAMILY PROPERTY IN EUROPE 65, 73 (Katharina Boele-Woelki, Jo Miles \& Jens Scherpe eds. 2011).

337. Id. See also Hayley Trim, Radmacher v. Granatino: The Wait is Over, 40 FAM. LAW 1185 (2010). For a discussion of English law regarding premarital agreements before McLeod and Radmacher, see Nigel Lowe \& Roger Kay, The Status of Prenuptial Agreements in English Law Eccentricity or Sensible Pragmatism?, in FAMILY FINANCES 395 (Bea Verschraegen ed. 2009).

338. See Bill Atkin \& Wendy Parker, RELATIONSHIP PROPERTY IN NEW ZEALAND 193 (2d. ed. 2009) (discussing § $21 \mathrm{~F}$ of the Property (Relationships) Act of 1976).

339. See id.

340. Id. at 194 (discussing § 21J of the Property (Relationships) Act of 1976).

341. Id. at 196.

342. Id.

343. See Belinda Fehlberg \& Bruce Smyth, Binding Pre-nuptial Agreements in Australia: The First Year, 16 INT'L J. L. POL'Y \& FAM. 127, 128, 130-31 (2002). 
maintenance. ${ }^{344}$ Enforcement can be avoided, however, if circumstances change during marriage so that enforcement would be "impracticable." 345 Another ground for avoiding an agreement is unconscionable conduct. ${ }^{346}$ Maintenance restrictions are not enforced if a party would thereby qualify for a government benefit. ${ }^{347}$ An agreement can also be set aside due to fraud. ${ }^{348}$ If the agreement was executed under coercive circumstances, the agreement may be invalidated. ${ }^{349}$

Certain amendments were made to Australian premarital agreement rules, effective in January 2010. The most important of these gives a court the right to enforce an agreement if "it would be unjust and inequitable" not to enforce it, even if certain procedural requirements, such as the receipt of independent legal advice, were not followed. 350 However, courts are given no guidance about how to make the determination whether it would be "unjust and inequitable" not to enforce the agreement. ${ }^{351}$

\section{Canada}

In Canada premarital agreements contemplating the economic consequences of divorce are generally valid. ${ }^{352}$ These agreements are regulated by provincial law, not federal law. ${ }^{353}$ Some provincial laws provide grounds to invalidate such agreements. In Ontario, Canada's largest province, premarital agreements may not impact rights in the matrimonial home. ${ }^{354}$ Enforcement of an agreement can be avoided if a party failed to disclose significant assets at the time of execution ${ }^{355}$ or if the waiving party did not understand the nature and consequences of the contract. 356 Prior to signing an agreement, the parties must disclose their assets as well as the value of those assets. ${ }^{357}$ In one case, the agreement was not enforced where the wealthy spouse did not accurately disclose the value of his assets and encouraged the other party to fire her

\footnotetext{
344. Id. at $129-30$.

345. Id. at 131; Patrick Parkinson, Setting Aside Financial Agreements, 15 AUSTL. J. FAM. L. 26, 45 (2001).

346. See Parkinson, supra note 345 , at 48.

347. See Owen Jessep, Section 90G and Pt. VIIIA of the Family Law Act 1975 (Cth), 24 AusTL. J. FAM. L. 104, 105 (2010).

348. See Blackmore \& Webber (2009) FMCA Fam. 154 (noting that, where the husband's
} nondisclosure of financial information was found to be fraud,the agreement was not enforced); Grant \& Grant-Lovett (2010) FMCA Fam. 162 (noting that, where the husband's nondisclosure of financial information was found to be fraud, the agreement was not enforced).

349. See Blackmore \& Webber, supra note 348.

350. See Jessep, supra note 347 , at 110-13.

351. Id.

352. See Stephen Grant, Prenuptial Agreements in Canada: The Exceptions Make the Rules, in INTERNATIONAL PRE-NuPTIAL AND POST-NuPTIAL AGREEMENTS 101, 101 (Family Law 2011).

353. See id.

354. See Hugh STARK \& KIRSTIE MACLISE, DOMESTIC CONTRACTS (Thomson Reuters Canada) (discussing § 52 of the Ontario Family Law Act).

355. Id. (discussing § 56(4) of the Family Law Act).

356. Id.

357. Id. (citing Dubin v. Dubin, 34 R.F.L. (5th) 227 (Ont. S.C.J.)). 
aggressive and zealous lawyer and instead hire another more compliant lawyer at the last minute. 358 Under Ontario law, the waiving party must "understand the nature and consequences" of the agreement for it to be enforceable. ${ }^{359}$ Although consultation with independent counsel is not expressly required, obtaining independent legal counsel is the best way of satisfying this requirement. ${ }^{360} \mathrm{~A}$ waiver of spousal support is not enforceable if it would cause "unconscionable circumstances." 361

In British Columbia, legislation gives a court discretion to not enforce the property provisions of a contract if it is "unfair" at divorce. ${ }^{362}$ In one case, a pregnant woman signed a premarital agreement on her wedding day that waived most of her rights to division of marital property. ${ }^{363}$ She had independent legal advice, the groom fully disclosed the extent of his assets, and there was no attempt to restrict spousal support. ${ }^{364}$ In spite of the wife's claim that her pregnancy and the timing of her signing of the premarital agreement made it unfair, the Supreme Court of Canada upheld the agreement. ${ }^{365}$ Restrictions on the right to spousal support are more closely reviewed for unfairness. ${ }^{366}$

\section{E. Western Europe}

In many Western European countries, the default marital regime for spouses is one of community property of acquests. ${ }^{367}$ Spouses normally retain the right to select another regime such as separation of property. 368 Under that alternative, there is no sharing of property either during or at the end of marriage. ${ }^{369}$ To choose an alternate regime, spouses must sign a written agreement before marriage; prior to doing so, most countries require they meet with a notary who explains to both parties the impact of the agreement. ${ }^{370}$ In

358. See Nicholas Bala, Case Comment on LeVan v. LeVan: Over-Reaching in the Formation of a Prenuptial Contract, 32 R.F.L. (6th) 374 (2007).

359. Id.

360. Id. Another commentator has said that it would be a "rare case" where an agreement would be enforced in Ontario if both parties did not have independent counsel. See Grant, supra note 352, at 105-06. In Alberta and New Brunswick, legislation expressly provides that a premarital agreement is enforceable only if both parties have independent legal counsel. See id. at 105 n.18.

361. See id. at 106-07.

362. Id.

363. See id.

364. See id.

365. Id. See also Martha Shaffer, Domestic Contracts, Part II: The Supreme Court's Decision in Hartshorne v. Hartshorne, 20 CAN. J. FAM. L. 261 (2004).

366. See Bala, supra note 358.

367. See generally FAMILY LAW IN EUROPE (Carolyn Hamilton \& Alison Perry eds., 2d ed. 2002). This type of community property system is the one accepted in the United States. As a general rule, parties jointly own property accumulated by either spouse during marriage due to effort, while they do not share premarriage acquisitions by either spouse or a gift or inheritance received by either spouse during marriage. Id.

368. Id.

369. Id.

370. Id. 
some countries, parties may not restrict post-divorce spousal support in a premarital agreement. ${ }^{371}$

Although some countries permit marital contracts selecting a regime of separate property to be challenged at divorce on the ground of unfairness, 372 in most countries such a selection will be enforced at divorce. ${ }^{373}$ A few countries have created a system of compensatory payments after divorce that cannot be limited by a premarital agreement. ${ }^{374}$ Provisions restricting the right to spousal support, where permitted, are scrutinized more rigorously for fairness. ${ }^{375}$

\section{F. Summary}

In many jurisdictions outside the United States, to make an enforceable premarital agreement both parties must consult with independent counsel or a civil law notary. In most, there are significant restrictions on the right to limit post-divorce support or there is judicial review of the agreement at the time of divorce to see whether enforcement would impose an undue hardship on either party.

\section{PROPOSED REVISIONS TO THE UPAA}

\section{A. Procedural Revisions}

\section{i. Clarifying What Constitutes Voluntary Execution}

Many United States courts now let the wealthy party "sandbag" the other in premarital agreement negotiations, allowing the party in favor of the agreement to wait until a day or two before the wedding to present a draft of a premarital agreement. ${ }^{376}$ This forces the less sophisticated party, at the last minute, to try to locate a lawyer and decide whether to sign the agreement or cancel the wedding. This is hugely unfair, wrong, and cries out for change.

The New Hampshire Supreme Court has been critical of such bargaining strategies. In re Estate of Hollett, 377 for example, involved a wealthy spouse who mentioned the possibility of a premarital agreement two years before the eventual wedding date. ${ }^{378}$ The poorer spouse strongly objected, and the spouse

371. See Nina Dethloff, Arguments for the Unification and Harmonization of Family Law in Europe, in PERSPECTIVES FOR THE UNIFICATION AND HARMONIZATION OF FAMILY LAW IN EUROPE 50 n.74 (Katharina Boele-Woelki ed., 2003) (referring to Italy, the Netherlands, and Switzerland). See also Dethloff, Contracting in Family Law, supra note 336, at 82 n.122 (mentioning also Belgium, Denmark, Poland and Portugal).

372. See Dethloff, Arguments for the Unification and Harmonization of Family Law in Europe, supra note 371 , at $\S 2.3 .4$.

373. Id.

374. Id. at $\S 2.4$ (mentioning France as an example).

375. Id.

376. See, e.g., In re Marriage of Yannalfo, 794 A.2d 795 (N.H. 2002); Fletcher v. Fletcher, 628

N.E.2d 1343 (Ohio 1994); Williams v. Williams, 720 S.W.2d 246 (Tex. App. 1986).

377. 834 A.2d 348 (N.H. 2003).

378. Id. at 350 . 
arguing for the agreement said nothing further. ${ }^{379}$ In holding the agreement invalid, the court stated:

[A]lthough John's lawyers had drafted a prenuptial agreement almost a month before the wedding, John did not obtain counsel for his wife or even inform her of the agreement until several days before the ceremony. In other words, despite having every opportunity to negotiate the agreement well before the wedding, John elected to conduct his affairs so that Erin had no time to choose her own counsel, and very little time to negotiate and reflect upon the agreement. ${ }^{380}$

As discussed above, courts often analyze the issue of whether an agreement was voluntary signed by asking whether the spouse being asked to waive rights was compelled to sign the agreement. ${ }^{381}$ Because of this focus, many courts have held that an agreement should not be invalidated based on the fact that it was presented at the last minute. ${ }^{382}$

I would submit this is the wrong focus. Perhaps it is necessary to reframe the issue. The proposed model statute ${ }^{383}$ states that an agreement should not be enforced if the circumstances surrounding execution placed "undue pressure" on the party being asked to waive rights. 384 Such a revision of the standard would clarify that the issue is not "voluntariness" as that concept has been framed by most courts but whether the bargaining process was consistent with the confidential relationship that exists between prospective spouses. Did the spouse being asked to waive rights have a reasonable opportunity to decide whether to consult with independent counsel? Did that party have adequate time to consider any legal advice obtained? Did that spouse have a reasonable amount of time to decide whether to sign the agreement before the distractions and pressures of an impending wedding became overwhelming? In contrast, many courts today apply a much lower standard of review, upholding agreements even where unfair bargaining has occurred. For example, in Estate of Ingmand, 385 the court enforced the agreement despite the fact that it found one party had "tricked" the other and employed "surprise pressure tactics."386

Numerous courts have recognized that engaged people have a confidential or fiduciary relationship. 387 As the Washington Supreme Court observed:

\footnotetext{
379. Id.

380. Id. at 353.

381. Supra Part I. B. i.

382. See In re Marriage of Yannalfo, 794 A.2d 795, 797-98 (N.H. 2002); Howell v. Landry, 386 S.E.2d 610, 612 (N.C. Ct. App. 1989).

383. See infra Schedule A.

384. See id.

385. No. 00-1281, 2001 WL 855406 (Iowa Ct. App. July 31, 2001).

386. Id. at*3.

387. See Sogg v. Nevada State Bank, 832 P.2d 781, 784 (Nev. 1992); Cannon v. Cannon, 865 A.2d 563, 573 (Md. Ct. App. 2005); Griffin v. Griffin, 94 P.3d 96, 99-100 (2004); In re Estate of Hollett, 834 A.2d 348, 351 (N.H. 2003); In re Marriage of Drag, 762 N.E.2d 1111, 1116 (Ill. App. Ct. 2002); Wiley v. Iverson, 985 P.2d 1176, 1180 (Mont. 1999); Randolph v. Randolph, 937 S.W.2d 815, 821 (Tenn. 1996); Fletcher v. Fletcher, 628 N.E.2d 1343, 1346 (Ohio 1994); Carpenter v. Carpenter, 449 S.E.2d 502, 504 (Va. Ct. App. 1994); Pajak v. Pajak, 385 S.E.2d 384, 389 (W. Va. 1989); Tiryakian v. Tiryakian, 370 S.E.2d 852, 854 (N.C. Ct. App. 1988); Rosenberg v. Lipnick, 389 N.E.2d 385, 388 (Mass. 1979); Merrill
} 
Parties to a pre-nuptial agreement do not deal with each other at arm's length. Their relationship is one of mutual confidence and trust which calls for the exercise of good faith, candor and sincerity in all matters bearing upon the proposed agreement. The basic objective of this common sense rule is to prevent overreaching. ${ }^{388}$

Premarital agreements should not be governed by contract rules applicable to commercial contracts. The relationship of parties planning to marry in the near future is much more complex and, as the past forty years of premarital agreement bargaining and litigation have shown, a party may need additional protection from abusive bargaining tactics. For example, in California one spouse is barred from taking "unfair advantage" of the other. ${ }^{389}$ If the focus were shifted from voluntariness to undue pressure, such a standard would be more in keeping with the confidential relationship of the parties and would reduce the ability of one spouse to take unfair advantage of the other.

A new standard for premarital agreement bargaining could be implemented in the form of a general rule. For example, a statute could be enacted requiring that a premarital agreement be presented a sufficient time before the wedding so the party to whom the agreement is presented will have adequate time, without being placed under undue pressure, to: (i) consider whether to consult an attorney; (ii) locate and consult with independent counsel, if legal advice is desired; and (iii) decide whether to sign the agreement. Such a general standard would give courts some flexibility in applying the rule to different situations.

However, it could present some problems. First, some courts might construe such a general statute as not changing existing standards for determining whether to enforce a premarital agreement. Second, if the statute would be construed as changing existing standards, it would not be clear to parties what is required until case law developed clarifying the rule. I propose that a clear set of minimum bargaining rules would therefore be preferable.

U.S. law has long recognized that, even absent a confidential relationship, a party can be pressured into signing an agreement, and the agreement therefore should not be considered binding. For example, consumer protection laws sometimes give a party to such an agreement three to seven days to rescind the agreement. ${ }^{390}$ Of course, it would not be fair to allow a party to sign a premarital

v. Estate of Merrill, 552 P.2d 249, 250 (Or. 1976); Fick v. Fick, 851 P.2d 445, 449-450 (Nev. 1993); Newman v. Newman, 653 P.2d 728, 732 (Colo. 1982); Watson v. Watson, 126 N.E.2d 220, 222 (Ill. 1955); In re Broadie's Estate, 493 P.2d 289, 293 (Kan. 1972); Hartz v. Hartz, 234 A.2d 865, 870 (Md. 1967); In re Estate of Strickland, 149 N.W.2d 344, 351 (Neb. 1967); In re Estate of Serbus, 324 N.W.2d 381, 385 (Minn. 1982); Braddock v. Braddock, 542 P.2d 1060, 1062 (Nev. 1975); Kosik v. George, 452 P.2d 560, 563 (Or. 1969); In re Estate of Hillegass, 244 A.2d 672, 675 (Pa. 1968); Hook v. Hook, 431 N.E.2d 667, 669 (Ohio 1982).

388. Friedlander v. Friedlander, 494 P.2d 208, 213 (Wash. 1972) (en banc).

389. CAL. FAM. CODE $\S 721$ (West 2004). See, e.g., In re Marriage of Balcof, 47 Cal. Rptr. 3d 183 (Cal. Ct. App. 2006).

390. See CAL. CIV. CODE $\S 1689.6$ (b) (West 2011) (stating that a buyer has a seven-day right to cancel a home solicitation contract for a personal emergency response unit); ME. REV. STAT. ANN. tit. 9-A, § 3-502(1-A) (2009) (stating that a buyer has a ten-day right to cancel a home food service plan); N.D. CENT. CODE § 51-02(1) (stating that a buyer older than sixty-four has fifteen days to cancel a home solicitation contract); FLA. R. CT. 12.740(f)(1) (2011) (stating that counsel not present at a 
agreement the day of the wedding, marry, and then rescind the agreement a few days after the wedding. Another way to reduce the likelihood that a prospective spouse will agree to an oppressive premarital agreement as a result of lastminute pressure is to slow down the negotiations. Requiring a "cooling-off period" would allow the party to whom the agreement is presented to consider whether to retain counsel or ask for modifications to the agreement, as well as whether to refuse to sign it. 391

California has already adopted one type of cooling-off period for premarital agreements. ${ }^{392}$ The statute provides that an agreement will be considered voluntarily signed only if, among other things, at least seven days passed between the day the final version of the agreement was presented and when it was signed. ${ }^{393}$ The appropriate amount of time for such a cooling-off period is debatable; seven days certainly is better than nothing, but it may be difficult, particularly for relatively unsophisticated parties, to find a lawyer within seven days.

My proposal is not identical to California's waiting period requirement, which has been construed to require a seven-day waiting period after the agreement is finalized. ${ }^{394}$ In contrast, my proposal only requires that the agreement not be signed until seven days after the first draft is presented; the parties would be free to negotiate and make revisions during that period. ${ }^{395}$

Also, the California provision has been construed to apply only if a party is not represented by counsel. ${ }^{396}$ The waiting period I propose would apply to both represented and unrepresented parties. 397 The primary purpose of this proposal is to make it impossible for the agreement to be signed without giving the party to whom the agreement is presented a period of time to consider whether to sign the agreement, consult an attorney, or request changes in the agreement. ${ }^{398}$ It is true that such a waiting period is not normally required before parties can make an enforceable agreement; however, in light of the confidential relationship that exists between an engaged couple and the history of abusive bargaining that has recently become common, such a waiting period is a desirable and necessary precaution.

In addition to the waiting period requirement, other safeguards are needed. The ALI has proposed that, to give rise to a presumption that the agreement was voluntarily signed, the agreement must be signed by both parties at least thirty

mediation may cancel a mediated settlement agreement within ten days); ARK. CODE ANN. § 18-14703(a) (2003) (stating that a buyer of a camping site time share has five days to cancel).

391. See generally Colin Camerer et al., Regulation for Conservatives: Behavioral Economics and the Case for "Asymmetric Paternalism," 151 U. PA. L. REV. 1211, 1238 (2003) (discussing the benefits of a cooling-off period in certain situations).

392. CAL. FAM. CODE $§ 1615$ (c) (West 2004).

393. Id.

394. See In re Marriage of Cadwell-Faso and Faso, 2011 WL 72179 at *1 (Cal. Ct. App. Jan. 11, 2011).

395. See infra Schedule A.

396. Id.

397. Id.

398. Id. 
days before the wedding. ${ }^{399}$ This requirement would deter last minute bargaining and encourage prospective spouses to finalize such agreements before the frenzy of the wedding weekend. A similar rule of thumb-that premarital agreements should be signed at least a month before the weddingappears to be evolving in England. 400

Although it would certainly be wise to finalize such agreements long before the wedding date, a question remains: if a black letter rule is to be established, what should be the cut-off date? Given the common practice of last-minute bargaining in the U.S., a change to thirty days before the wedding may be too drastic to try to impose at this time. My proposed statute provides that agreements generally must be finalized and signed seven days before the wedding. ${ }^{401}$ (A rebuttable presumption of undue pressure arises if the agreement is signed within seven days of the wedding. ${ }^{402}$ ) Although some might prefer the ALI's suggested time period of thirty days, if this more modest proposal of seven days were accepted it would significantly improve the fairness of premarital agreement bargaining in the U.S. while not being too inconvenient for the parties.

It is not unheard of to require that a contract be signed a certain number of days before an important event that could catalyze a significant amount of emotion. For example, Texas has adopted a set of rules for drafting an enforceable surrogacy agreement. ${ }^{403}$ The statute requires, among other things, that the agreement be signed at least fourteen days before the embryo is implanted in the gestational mother. ${ }^{404}$ Among other things, this fourteen-day requirement gives the woman at least two weeks to change her mind after signing the agreement but before the process is begun.

So, I would propose that, to improve the bargaining process for premarital agreements, as a general rule: (i) the agreement cannot be signed until a specified number of days have elapsed after a draft agreement is first presented, and (ii) the final agreement generally must be signed by both parties a specified number of days before the wedding. The New Hampshire Supreme Court has stated that "[i]ndependent counsel is useless without the ability and the time to make effective use of such counsel." 405 This proposed rule attempts to ensure that the party being asked to waive rights has adequate time to locate and consult independent counsel.

The ALI Principles provide that, if the circumstances surrounding execution do not meet the standards set forth in Section 7.04(3) (such as being signed at

399. See AMERICAN LAW INSTITUTE, PRINCIPLES OF THE LAW OF FAMILY DisSOLUTION: ANALYSIS AND RECOMMENDATIONS (2002) (hereinafter "ALI PRINCIPLES") § 7.04(3).

400. See Romantic Small Print: England's Supreme Court Upholds Prenuptial Agreements, ECONOMIST, Oct. 21, 2010, http:/ / www.economist.com/node/17311887.

401. See infra Schedule A.

402. Id.

403. See TEX. FAM. CODE. ANN. § 160.754(e) (Vernon 2011).

404. See id.

405. In re Estate of Hollett, 834 A.2d 348, 353 (N.H. 2003). 
least thirty days before the wedding), no presumption arises regarding duress. ${ }^{406}$ Given how courts have dealt with this problem in the past, the statute should be drafted such that the agreement is presumed unenforceable if the circumstances surrounding execution do not meet the requirements discussed above regarding a minimum time to deliberate and signing at least a certain number of days before the wedding. If the circumstances surrounding execution do meet the standards set forth, the agreement would be presumed valid. Agreements that do not meet these standards presumptively should not be enforced except in those instances where parties have already informally reached an agreement regarding all material terms weeks before the wedding and memorialize it within two days of the wedding 407 or where the negotiations have been continuing for a significant period and the agreement is finally signed within two days of the wedding.

Gardner v. Gardner 408 serves as an example where an agreement signed fewer than seven days before the wedding should be enforced. In Gardner the party being asked to waive rights had a lawyer and received the initial draft of the agreement more than two months before the wedding. ${ }^{409}$ The parties exchanged proposed drafts and signed the final agreement three days before the wedding. ${ }^{410}$

In addition, my proposal creates a conclusive presumption of undue pressure if the agreement is signed within forty-eight hours of the wedding. ${ }^{411}$ This would be true regardless of the sophistication of the parties or the presence of independent counsel.

An example of how this rule would affect current law can be seen by considering Winchester $v$. McCue. ${ }^{412}$ In this case, the first draft was provided seven days before the wedding, seven drafts were exchanged, and the parties signed the final agreement hours before the wedding. ${ }^{413}$ The waiving party was a lawyer who had independent counsel. ${ }^{414}$ Under the proposed schedule, a conclusive presumption of undue pressure would exist.

The most significant impact of the acceptance of the bargaining rules I have proposed is that it is unlikely an agreement first presented fewer than fourteen days before the wedding will be enforced. Agreements first presented a few days before the wedding would almost never be enforced.

406. See ALI PRINCIPLES, supra note 399, at 964-65.

407. As Brian Bix has noted, there could be a muddy distinction between situations where parties have discussed a premarital agreement and situations where they have agreed to all material terms. See Brian Bix, Bargaining in the Shadow of Love: The Enforcement of Premarital Agreements and How We Think About Marriage, 40 WM. \& MARY L. REV. 145, 188 (1998).

408. 527 N.W.2d 701 (Wis. Ct. App. 1994).

409. Id. at 705-06.

410. See also Francavilla v. Francavilla, 969 So.2d 522 (Fla. Dist. Ct. App. 2007); Robinson v. Robinson, 64 So.3d 1067 (Ala. Civ. App. 2010).

411. See infra Schedule A.

412. 882 A.2d 143 (Conn. Ct. App. 2005).

413. Id. at 145 .

414. Id. 


\section{ii. Disclosure of Financial Information}

Under the UPAA, inadequate disclosure of financial information is grounds for invalidating an agreement only if: (i) the party did not waive the right to receive such information, (ii) the party did not otherwise have access to such information, and, most surprisingly, (iii) the agreement was unconscionable when signed. ${ }^{415}$

The UPAA rule that inadequate disclosure is grounds for invalidating the agreement only if it is also unconscionable when signed is unusually restrictive. In a majority of U.S. jurisdictions, inadequate disclosure alone is enough to invalidate the agreement. ${ }^{416}$ I would encourage the revision of the UPAA to follow this majority rule. ${ }^{417}$ Before a premarital waiver of financial rights may be enforced at divorce, it should be shown that the waiving party was already familiar with the other party's financial condition or received adequate disclosure of such information in connection with the negotiation and execution of the agreement.

The UPAA permits a party to waive the right to disclosure. To ensure that any waiver of rights is a "knowing" waiver, particularly if independent counsel is not to be required, a waiver of disclosure should not be permitted.

iii. Understanding the Consequences of the Agreement

Numerous jurisdictions outside the U.S. enforce premarital agreements only where the waiving party understood the impact of the premarital agreement when it was signed; most require independent counsel or a consultation with a civil law notary.418 In addition, in a recent attempt to clarify English law, the Supreme Court of England stated that a premarital agreement should be enforced "where the parties were informed of its implications." 419 The English Law Commission proposed, in a recent Consultation Paper pertaining to marital property agreements, that an agreement should be enforced only if both parties received independent counsel. ${ }^{420}$ To date, U.S. jurisdictions do not require both parties to a premarital agreement have independent counsel. ${ }^{421}$ (This may in part be due to the added cost of such a requirement.) ${ }^{422}$ In a number of cases, the waiving party at divorce claimed that the scope and effect of the agreement was

415. See Unif. Premarital AgreEment ACt, § 6, 9C U.L.A. $48-49$ (2001).

416. See supra Part III. B.

417. Some "adopting" states made this change, such as Connecticut, Iowa, Nevada, and New Jersey. See supra Part II. B. iv. Professor Atwood has endorsed this change. See Atwood, supra note 45 , at 149 .

418. See supra Part V.

419. See supra Part II. B. iv.

420. ENGlish LAW COMMISSION, CONSUltation PAPER No. 198, MARITAL PROPERTy AGREEMENTS 107 (2011).

421. See supra Part III. C.

422. A recent study commissioned by the English Law Commission found that English lawyers reported an average legal fee charged for representing a party in connection with a premarital agreement of approximately $£ 5400$, or a little more than $\$ 8,000$. LAW COMMISSION REPORT: A STUDY OF THE VIEWS AND APPROACHES OF FAMILY PRACTITIONERS CONCERNING MARITAL PROPERTY AGREEMENTS, at 52-53. 
misrepresented when presented. ${ }^{423}$ In light of past U.S. reluctance to adopt a requirement that each party have independent counsel, it would be unwise to suggest such a requirement in any U.S. uniform law. But if each party does not have a lawyer, how could it be made more likely that both parties at least understand the basic effect of the agreement? ${ }^{424}$

As mentioned above, many states require, as a condition of enforcing a waiver of economic rights upon divorce, that the waiving party had sufficient information regarding the financial condition of the other party to have a general idea of what he or she was being asked to waive. U.S. courts have been less concerned about whether the party waiving the rights understood the legal significance of what was being signed.

The current California statute provides some guidance about how this could be accomplished. ${ }^{425}$ To create an enforceable premarital agreement, if the waiving party is not represented by independent counsel, before execution the other party must give the waiving party a written summary of "the terms and basic effect of the agreement as well as the rights and obligations he or she [is] giving up by signing the agreement." 426 The ALI makes a similar suggestion that a presumption of voluntary execution could be established by adding such a summary to the agreement itself. 427 It is not clear that the summary contemplated by the ALI proposal would be clearly visible; there is no requirement that the summary be in bold-faced type, for example. It would be preferable to provide the summary in a separate document to the unrepresented party before the agreement is signed, as is required in California. This requirement should be incorporated into a revised UPAA to help unrepresented parties understand the effect of the proposed agreement before it is signed.

423. See, e.g., Ware v. Ware, 7 So.3d 271 (Miss. Ct. App. 2008); Liebelt v. Liebelt, 801 P.2d 52 (Idaho Ct. App. 1990).

424. Studies suggest that Americans generally are not familiar with legal rules. See generally Lynn A. Baker, Promulgating the Marriage Contract, 23 U. MicH. J.L. ReFORM 217, 234-36 (1989). See also Lynn A. Baker \& Robert E. Emery, When Every Relationship Is Above Average: Perceptions and Expectations of Divorce at the Time of Marriage, 17 LAW \& HUM. BEHAV. 439, 441-45 (1993) (finding that people about to marry were not very familiar with rules applicable to marriage and divorce); Heather Mahar, Why Are There So Few Prenuptial Agreements?, HARVARD LAW SCHOOL JOHN M. OlIN CENTER FOR LAW, ECONOMICS AND BUSINESS DISCUSSION SERIES, Paper 436 (2003), available at http://lsr.nellco.org/harvard_olin/436 (finding also that people who had recently applied for a marriage license had little knowledge about how marriage affected their rights). Some commentators have argued that both parties should be required to have independent counsel in the U.S. See Gail Frommer Brod, Premarital Agreements and Gender Justice, 6 YALE J.L. \& FEMINISM 229 (1994); Judith T. Younger, Lovers' Contracts in the Courts: Forsaking Minimum Decencies, 13 WM. \& MARY J. WOMEN \& L. 349 (2007); Bix, supra note 407, at 207; David Westfall, Unprincipled Family Dissolution: The ALI's Recommendation for Division of Property, in RECONCEIVING THE FAMILY (Robin Wilson ed. 2006) 180.

425. CAL. FAM. CODE § 1615(c)(3) (West 2004).

426. Id. If the right to spousal support is impacted, the waiving party must have counsel.

427. See ALI PRINCIPLES, supra note 399, at $\$ 7.04$ (3)(c). In Texas, spouses can agree to transform separate property into community property. Such an agreement is enforceable, however, only if the agreement sets forth the legal effect of converting property from separate to community. See TEX. FAM. CODE ANN. § 4.205(a)(2) (Vernon 2011). 


\section{iv. Summary}

I am proposing that premarital agreements be enforced only if the circumstances surrounding execution satisfy various specific bargaining safeguards. Many U.S. courts over the past few decades have permitted oppressive and unfair bargaining in connection with premarital agreements, and clearly defined bargaining limits need to be promulgated.

Even if the drafters of the revised UPAA decide to retain a set of rules giving parties substantial assurance that an agreement will be enforced, it is difficult to quarrel with more robust, while still reasonable, procedural safeguards where the ground rules are clearly set forth. If more substantial procedural safeguards would be added to existing requirements, the party desiring an enforceable agreement merely would need to be sure that the circumstances surrounding execution comply with this new set of rules.

\section{B. Limiting the Enforcement of Agreements Due to Substantive Fairness \\ Concerns}

In addition to the procedural requirements discussed in the preceding section, a separate, and perhaps more difficult, issue is whether parts or all of a premarital agreement should not be enforced due to substantive fairness concerns. A question related to the latter issue is whether any limits should be placed on the ability of parties to change the rules governing the economic consequences of divorce.

\section{i. Restrictions Upon or Waivers of the Right to Spousal Support}

It seems fair to say that there is no U.S. consensus regarding the extent to which parties should be able to restrict the right to spousal support. The UPAA allows waivers of spousal support unless the waiving spouse would become a public charge. ${ }^{428}$ If the spouse would thereby become a public charge, the court is authorized to award such support so that the waiving party would not qualify for public benefits. ${ }^{429}$

A number of other states have established more limits upon the ability of parties to restrict the right to spousal support. For example, even some adopting states bar restrictions on the right to spousal support. ${ }^{430}$ In California, a restriction on spousal support is only enforceable if the party agreeing to the restriction was represented by independent counsel. Such a restriction will not be enforced even with advice of counsel if the provision is unconscionable at divorce. 431

In Colorado, spousal support restrictions are unenforceable if the waiving party would as a result not be able to provide for his or her reasonable postdivorce needs. ${ }^{432}$ Another approach is to not enforce such a waiver if the

428. See Unif. PREMARITAL AgreEMENT ACt, \$ 6, 9C U.L.A. 48-49 (2001).

429. Id.

430. See supra Part II. B. iii. (mentioning Iowa, South Dakota, and New Mexico).

431. See Cal. FaM. CODE $\$ 1615$.

432. See In re Marriage of Dechant, 867 P.2d 193 (Colo. App. 1993). 
waiving party would thereby experience a substantial change in circumstances from the marital standard of living after divorce. ${ }^{433}$

In Indiana, spousal support restrictions are not to be enforced if they would result in "extreme hardship." 434 Illinois bars the enforcement of such restrictions if the restrictions would cause "undue hardship" as a result of an unforeseeable change of circumstances during marriage. ${ }^{435}$ In other states, where an agreement is not to be enforced if unconscionable at divorce, courts have been more inclined to find unconscionability if there was a waiver of both equitable distribution and the right to spousal support. 436

In a few states, the right to spousal support may not be impacted. In many states, there is almost total contractual freedom, while in a number of others a restriction on spousal support is subject to some sort of fairness review. Given this lack of agreement, what might be a sensible compromise?

One option would be to distinguish between marriages where parties raise a common biological or adoptive child and childless marriages. In relationships where the parties raise children, the primary caretaker customarily incurs lifetime career damage.437 This damage can leave the primary caretaker economically vulnerable in the event of divorce, and the damage may be unforeseeable before the parties marry. 438 Because of this unique aspect of marriages with children, couples in childless marriages should be free to restrict or eliminate spousal support while those who raise children together should not.

This proposed change would not place a dramatic restriction on the ability of couples with children to modify their rights upon divorce. For example, consider the result in Gross v. Gross. 439 There the wealthy party was able to retain the $\$ 6,000,000$ that had been accumulated during marriage, but the premarital agreement's support restriction was not enforced, so the waiving party received indefinite monthly support of $\$ 2,500.440$ This result is vastly different from what would have occurred absent an agreement.

Similarly, in Millstein v. Millstein, ${ }^{41}$ the husband had assets worth \$28 million when the marriage began; after nineteen years of marriage his net worth was $\$ 120$ million. ${ }^{442}$ The court upheld the agreement waiving equitable distribution and awarded the wife indefinite monthly alimony of $\$ 9,000.443$

433. See Rogers v. Gordon, 961 A.2d 11 (N.J. Super. Ct. 2008).

434. See IND. CODE. ANN. § 31-11-3-8 (West 2001)

435. See 750 ILL. COMP. STAT. 10/7(b) (West 2009).

436. See supra notes $257-70$ and accompanying text.

437. See generally Cynthia Lee Starnes, Mothers as Suckers: Pity, Partnership, and Divorce Discourse, 90 IOWA L. REV. 1513, 1519-27 (2005). See also J. Thomas Oldham, 80 CALIF. L. REV 1091 (1992) (book review); David Leonhardt, The Different Costs of Motherhood, N.Y. TIMES (Dec. 18, 2010), http:/ / economix.blogs.nytimes.com/2010/12/18/the-different-costs-of-motherhood/.

438. See Starnes, supra note 437.

439. 464 N.E.2d 500 (Ohio 1984).

440. See id. at 510 .

441. 2002 WL 31031676 (Ohio Ct. App. 2002).

442. Id. at *10, ${ }^{*} 15$.

443. Id. at $* 19$. 
Likewise, in Lane $v$. Lane, ${ }^{444}$ the court enforced the waiver of equitable distribution-thereby allowing the wealthy spouse to retain most of the property-but declined to enforce the maintenance waiver, so the waiving party was awarded a monthly payment of $\$ 12,000$ for three years. ${ }^{445}$

The approach suggested here would always give the court the power, in those marriages where the parties raised children, to award support to a dependent spouse upon divorce. In contrast, parties in childless marriages generally would be able to restrict or eliminate the possibility of spousal support if they so desired.

\section{ii. Not Enforcing an Agreement Due to Substantive Unfairness}

If the proposals suggested above are enacted, is there a need for any type of fairness review of premarital agreements? Under the UPAA, substantive fairness is considered only at the time of execution, and an agreement is unenforceable only if found "unconscionable" at that time and the waiving party did not have adequate information regarding the other party's financial condition. 446 Two features of the UPAA rule should be noted. On one hand, the focus is on the time of execution, not enforcement. In addition, an agreement is enforceable-in spite of its unconscionability upon execution-if the waiving party had adequate financial information or waived the right to such information. In many other non-UPAA states, the focus is on the unconscionability of the agreement at the time of enforcement, not execution, and a finding of unconscionability alone is sufficient to render an agreement unenforceable. ${ }^{447}$

This is consistent with the evolving rules in other jurisdictions. A recent

444. 202 S.W.3d 577 (Ky. 2006).

445. Id. at 579 .

446. See UNIF. PREMARITAL AgreEMENT Act, § 6, 9C U.L.A. $48-49$ (2001).

447. See supra Part IV. A. This is true in some states that adopted the UPAA with some changes, such as Connecticut, New Jersey, and North Dakota. See ConN. GEN. STAT. ANN. \$46b-36g(a)(2) (West 2009); N.J. STAT. ANN. §37:2-37 (West 2002); N.D. CENT. CODE § 14-03.1-07 (2009).

I have discussed elsewhere the appropriate time for a review of the unconscionability of a premarital agreement:

Admittedly, courts normally determine the unconscionability of a commercial contract according to the circumstances existing at the time of execution. Still, marital contracts are somewhat different from commercial transactions. First, in marital contracts spouses plan for what will occur at dissolution. The marriage, however, may not be dissolved for decades. The term of most commercial contracts is much shorter. Second, important public policy concerns relate to the circumstances of the spouses at divorce, not at the time the contract was signed. The circumstances of spouses can change dramatically during a marriage. For example, one spouse may develop health problems or may have a diminished earning capacity as a result of working solely as a homemaker. Few would dispute that the state has a strong interest in attempting to ensure that each spouse will be financially self-sufficient after divorce, and that any children will be adequately supported. Consequently, the state has a strong interest in policing the substantive fairness of the division of property at divorce. The circumstances of the parties at the time the marital contract was signed are irrelevant to these public policy concerns. So, the ... focus upon the fairness of a marital contract solely at the time of execution seems unwise. If substantive fairness is to be relevant to the question of enforceability of marital contracts, the focus should be upon the fairness of the contract at divorce.

J. Thomas Oldham, Premarital Agreements Are Now Enforceable, Unless ..., 21 Hous. L. Rev. 757, 775-76 (1984) (citations omitted). 
English decision states that marital agreements should be enforced only if they are "fair" and there has not been a change in the parties' circumstances so enforcement of the agreement would not be "manifestly unjust."448 In New Zealand, an agreement is not to be enforced if it would cause "serious injustice." 449 If there was unconscionable conduct, the agreement is not to be enforced in Australia.450 "Unfair" agreements are not enforceable in British Columbia. 451

Some commentators have been critical of the lack of a significant review of the substantive fairness of premarital agreements at divorce. ${ }^{452}$ A few urge a return to the old rule that premarital agreements attempting to change the rules governing the economic consequences of divorce should not be permitted. ${ }^{453}$ Other commentators have proposed a more rigorous review of the substantive fairness of agreements at the time of divorce. ${ }^{454}$ Professor Brod has proposed that an agreement should be reviewed at divorce for its "economic justice." 455 Another has suggested that courts should consider an agreement that does not provide for an approximately equal division of marital property presumptively unenforceable. ${ }^{456}$ Professors Atwood and Younger have argued that agreements that are unconscionable at divorce should not be enforced. ${ }^{457}$

The ALI Principles also suggest a relatively substantial fairness review of an agreement at divorce. ${ }^{458}$ Under the ALI, an agreement is not to be enforced if the objecting party can establish that enforcement would "work a substantial injustice." 459

The current UPAA position regarding the level of substantive fairness review at divorce is significantly different from the scrutiny applied in many jurisdictions, as well as the recommendation made in the ALI Principles and by numerous U.S. commentators. An apparent concern of the UPAA drafters was to provide a set of rules that would result in agreements being enforced in almost all instances. Of course, it does seem important to promulgate a set of rules that will generally allow parties to predict when agreements will be enforced. However, there are other legitimate societal concerns that arise when

448. See supra notes 327-31 and accompanying text.

449. See supra notes 340-41 and accompanying text.

450. See supra note 346 and accompanying text.

451. See supra note 362 and accompanying text.

452. See Jeffrey G. Sherman, Prenuptial Agreements: A New Reason to Revive an Old Rule, 53 CLEVE. ST. L. REV. 359 (2006); Julia Halloran McLaughlin, Should Marital Property Rights Be Inalienable? Preserving the Marriage Ante, 82 NEB. L. REV. 460 (2003).

453. See Sherman, supra note 452; McLaughlin, supra note 452.

454. See Brod, supra note 424 (defining an economically unjust agreement as one where a party is significantly worse off economically than before marriage).

455. See id.

456. See Comment, Marriage as Contract and Marriage as Partnership: The Future of Antenuptial Agreement Law, 116 HARV. L. REV. 2075 (2003).

457. See Atwood, supra note 45; Judith T. Younger, Perspectives on Antenuptial Agreements: An Update, 8 J. AM. ACAD. MATRIM. LAW. 1, 42 (1992).

458. See ALI PRINCIPLES, supra note 399, at § 7.05.

459. See id. 
contemplating the extent to which parties should be able to modify the economic consequences of divorce. If a party will suffer substantial hardship after divorce due to the enforcement of an agreement, this hardship is a legitimate consideration when evaluating potential limits on parties' ability to change the rules applicable to the economic consequences of divorce. ${ }^{460}$

A potential compromise between the current UPAA position and the view proposed in the ALI Principles would be to enforce an agreement unless the court finds the terms are unconscionable at divorce. ${ }^{461}$ I have previously proposed another approach to this issue: courts should inquire whether there was a substantial and unforeseen change in the parties' circumstances during marriage. 462 My proposed standard reflects my previous recommendation.

This proposed standard should not result in wholesale invalidation of premarital agreements. As the discussion above shows, courts have only rarely invalidated agreements in states currently applying this standard. ${ }^{463}$

\section{CONCLUSION}

The National Conference of Commissioners on Uniform State Laws promulgated the UPAA about a decade after the concept of premarital agreements contemplating divorce was first tentatively accepted in the U.S. ${ }^{464}$ The fundamental goal of the UPAA drafters seemed to be to formulate a set of rules that would make it very likely premarital agreements would be enforced upon divorce. ${ }^{465}$ While this overarching goal may still be useful, it is clear that some revisions to the UPAA are now needed to protect parties from unfair bargaining tactics and the extreme unfairness which often results from substantial changes in the circumstances of the parties during marriage.

The UPAA's most glaring problem is that it has sanctioned oppressive bargaining. Courts have often enforced agreements where the more sophisticated party first presented the agreement a day or two before the wedding and informed the other (normally unsophisticated) party that the agreement must be signed or the wedding will be called off. This places the other party in an extremely difficult situation. It is quite unlikely that independent counsel can be located and consulted on such short notice. In addition, there is little time to consider any advice received or to reflect upon the agreement's terms and negotiate changes. The (normally unsophisticated) party being asked to waive rights therefore is forced to decide, frequently once

460. See generally Judith T. Younger, Perspectives on Antenuptial Agreements, 40 RUTGERS L. REV. 1059 (1988).

461. See id. at 1089-90; Ronald Ladden \& Robert Franco, The Uniform Premarital Agreement Act: An Ill-Reasoned Retreat from the Unconscionability Analysis, 4 AMER. J. FAM. L. 267, $274-77$ (1990); S. Christine Mercing, Comment, The Uniform Premarital Agreement Act: Survey of tis Impact in Texas and Across the Nation, 42 BAYLOR L. REV. 825 (1990); Suzanne Reynolds, Premarital Agreements, 13 CAMPBELl L. REV. 343 (1991).

462. See Oldham, Premarital Agreements Are Now Enforceable, supra note 447, at 778.

463. See supra Part IV.B.

464. UNIF. PREMARITAL AGREEMENT ACT, 9C U.L.A. 39 (2001).

465. Seeid. 
wedding festivities have already begun and without the benefit of independent counsel, whether to sign the agreement as presented or cancel the wedding. If a waiver of substantial rights in a premarital agreement is to be enforceable, a fairer system must be put in place to guarantee the waiver was freely and knowingly signed without undue pressure.

The model statute attached as Schedule A contemplates that the bargaining process could be improved by generally requiring that: (i) the party being asked to waive rights be given at least seven days after the agreement is first presented to consider whether to retain counsel, ask for revisions, and sign the agreement; and (ii) the agreement generally needs to be signed by both parties at least seven days before the wedding. ${ }^{466}$ An agreement signed within forty-eight hours of the wedding would never be enforced. ${ }^{467}$ These requirements would guarantee that the party being asked to waive rights would have more notice of the issue (at least two weeks before the wedding) than is common today and would have more time to consider whether to meet with independent counsel or negotiate changes. In addition, the proposal encourages parties to decide whether to sign the agreement or cancel the wedding a week before the wedding instead of (as commonly occurs now) when the wedding weekend had already begun. It is likely parties could make a more intelligent decision regarding whether to sign the agreement if the decision is made a week-not hours-before the wedding.

It is not uncommon for parties not represented by counsel to contend at dissolution of a marriage that they misunderstood the effect of the premarital agreement. ${ }^{468}$ Perhaps for this reason, some countries require both parties have independent counsel before a premarital agreement will be enforced. My proposal does not include such a requirement, at least in part because U.S. courts and legislatures have been so reluctant to accept such a requirement. This proposal does require that, if a party is not represented by counsel, and the other is, the other party (or the lawyer for that party) must give a written summary of the general effect of the agreement to the unrepresented party, in a document independent of the agreement itself, before the agreement is signed.469 The proposal also requires each party be "generally informed" regarding the assets and income of the other party; a waiver of this requirement is not permitted. ${ }^{470}$

These proposed changes to the rules governing whether to enforce a premarital agreement are suggested to make it more likely that the party being asked to waive rights will be aware of the agreement's impact on his or her rights and will have more time to consider whether to sign the proposed agreement or propose revisions. When compared to current law, the bargaining standards reflected in this proposal are more congruent with the confidential relationship that exists between people engaged to be married.

The attached proposal also includes substantive fairness limits on

466. See infra Schedule A.

467. See id.

468. See, e.g., In re Marriage of Shirilla, 89 P.3d 1 (Mont. 2004); In re Estate of Smid, 756 N.W.2d 1

(S.D. 2008); Holler v. Holler, 612 S.E.2d 469 (S.C. Ct. App. 2005).

469. See infra Schedule A.

470. See id. 
premarital agreements. Parties who raise one or more common biological or adoptive children are barred from restricting the right to spousal support. In addition, a court is instructed not to enforce the agreement if it would cause undue hardship to a spouse because the circumstances of the parties changed during marriage for reasons not foreseeable by the parties when they married. These provisions include some minimal protection for dependent spouses if a divorce occurs while still granting prospective spouses substantial freedom to modify customary economic consequences of divorce. 


\section{SCHEDULE A}

\section{Suggested Statutory Scheme to Regulate Premarital AgreEMENTS CONTEMPLATING DIVORCE}

\section{Enforcement}

A premarital agreement should be enforced if:

(a) circumstances surrounding execution did not place undue pressure on either party;

(b) each party was generally informed regarding the assets and income of the other party when the agreement was signed;

(c) each party generally understood the legal effect of the agreement; and

(d) enforcement would not cause undue hardship to either party due to a change in the parties' circumstances during marriage that was not foreseeable at the time the agreement was signed.

\section{Undue Pressure}

(a) A presumption arises that the circumstances surrounding execution of the agreement did not place undue pressure on either party if:

(1) the final agreement was signed a minimum of seven days after the initial written draft of the agreement was delivered to both parties; and

(2) the agreement was signed by both parties a minimum of seven days before the wedding.

(b) If the timing of the negotiation or execution of the agreement did not comply with section (2) (a) hereof, a rebuttable presumption arises that the circumstances surrounding execution placed undue pressure on the parties.

(c) A conclusive presumption that the circumstances surrounding execution of the agreement placed undue pressure on the parties shall arise if the agreement is signed within forty-eight hours of the wedding.

\section{Understanding the Legal Effect of the Agreement}

A party generally understands the legal effect of the agreement if:

(1) the party was represented by independent counsel selected by that party in connection with the negotiations regarding the agreement; or

(2) one party was not represented by independent counsel and the other party was represented, and the unrepresented party received from the other party before the agreement was signed a written summary of the terms and basic effects of the agreement as well as a general description of the rights he or she was giving up by signing the agreement.

If one party was represented by independent counsel and the objecting party did not receive legal advice, if the provisions of section 3(2) hereof were not complied with, the agreement should not be enforced. 


\section{Limiting Spousal Support}

Any term in the agreement restricting the right to claim post-divorce spousal support is not valid if the parties during marriage raised a common biological or adoptive child. 